\title{
Dosimetry Comparison of CBCT versus Digital 2D Orthodontic Imaging in a Pediatric Orthodontic Patient
}

\author{
AB Albin', AD Goren ${ }^{2,5 *}$, RD Faber ${ }^{1}$, NK Anderson ${ }^{4}$, LT Dauer ${ }^{3}$, B Quinn³ ${ }^{3}$ D Miodownik M Kelly $^{3}$, I

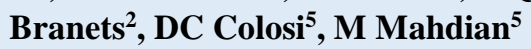 \\ ${ }^{1}$ Department of Orthodontics and Pediatric Dentistry, School of Dental Medicine, State University of New York \\ at Stony Brook, Stony Brook, NY, USA \\ ${ }^{2}$ Department of Cariology and Comprehensive Care, New York University College of Dentistry, New York, \\ NY, USA \\ ${ }^{3}$ Department of Medical Physics and Department of Radiology, Memorial Sloan-Kettering Cancer Center, New \\ York, NY, USA \\ ${ }^{4}$ Developmental Biology, Harvard School of Dental Medicine, Cambridge, MA, USA \\ ${ }^{5}$ Department of Prosthodontics and Digital Technology, School of Dental Medicine, State University of New \\ York at Stony Brook, Stony Brook, NY, USA \\ *Corresponding Author: Arthur D Goren, Department of Cariology and Comprehensive Care, New York \\ University College of Dentistry, New York and Department of Prosthodontics and Digital Technology, School \\ of Dental Medicine, State University of New York at Stony Brook, Stony Brook, NY, USA; \\ Email: ag153@nyu.edu
}

Received Date: 05-05-2021; Accepted Date: 27-04-2021; Published Date: 04-06-2021

Copyright $^{\circledR} 2021$ by Goren $\mathrm{AD}$, et al. All rights reserved. This is an open access article distributed under the terms of the Creative Commons Attribution License, which permits unrestricted use, distribution and reproduction in any medium, provided the original author and source are credited.

\begin{abstract}
The purpose of the study was to evaluate the amount of radiation potentially absorbed by a pediatric patient during whole-head $(13 \times 15 \mathrm{~cm})$ CBCT imaging compared with digital panoramic and lateral cephalometric imaging using the same machine. For each of the three imaging modalities, twenty-one nanoDot Optically Stimulated Luminescent Dosimeters (OSLDs) were placed in a pediatric anthropomorphic 10-year old phantom in order to record absorbed radiation doses at different radiosensitive locations. All imaging was performed using the manufacturer's recommended exposure settings. Ten more runs were performed with an OSLD placed only at the thyroid. A Monte Carlo Analysis was performed to extrapolate the absorbed doses for the remaining twenty organ locations. Equivalent doses for the head and neck organs and overall effective doses was determined using the International Commission
\end{abstract}

Goren AD | Volume 2; Issue 2 (2021) | JDHOR-2(2)-026 | Data Article

Citation: Goren AD, et al. Dosimetry Comparison of CBCT versus Digital 2D Orthodontic Imaging in a Pediatric Orthodontic Patient. J Dental Health Oral Res. 2021;2(2):1-28. 
on Radiological Protection's tissue weighting factor guidelines. For each of the organs tested, there was a statistically significant differences in radiation doses across the three imaging modalities. The highest radiation doses were observed in CBCT imaging for all organs. The average effective dose was higher in CBCT than in lateral ceph and panoramic imaging combined. The results of the study suggest that in order to reduce pediatric patient radiation exposure during routine orthodontic records, conventional 2D imaging with digital panoramic and lateral cephalometric modalities should be used preferentially over CBCT imaging.

\section{Keywords}

3D imaging; Panoramic Radiographs; Orthodontics; Salivary Glands; ANOVA

\section{Introduction}

With the advent of CBCT imaging, its use in orthodontics has grown exponentially. Initially used for specific diagnostic purposes, such as small volumes for the diagnosis of impacted cuspids, CBCT is increasingly being used for routine orthodontic diagnosis and treatment planning rather than traditional 2D imaging modalities [1-5].

Orthodontic diagnostic records serve to document the commencement of treatment and to supplement the clinical exam [6]. A thorough set of diagnostic records is crucial in properly diagnosing and treating orthodontic patients, and updated records are typically taken yearly that include photographs, panoramic, and lateral cephalometric radiographs. Imaging during treatment is used to evaluate the effects of treatment, and post-treatment imaging is used to evaluate outcomes [7-12].

As CBCT imaging continues to advance and reduce in cost, many practitioners are using this newer modality as a replacement for cephalometric radiographs. However, the use of 3D imaging as a replacement of panoramic and cephalometric radiographs in diagnosis and treatment planning of orthodontic cases is controversial [7].

Unfortunately, it is difficult for a governing organization or authority to create definitive rules regarding the appropriate time to take radiographs due to the nuances of clinical examination and the variations between different patients [4]. While the American Dental Association and the FDA has determined guidelines for taking bitewings with panoramic versus bitewings with select periapicals, no such guidelines exist for orthodontic imaging from these groups [13]. The American Association of Orthodontists 2017 "Clinical Practice Guidelines for Orthodontics and Dentofacial Orthopedics" states that the current standard of care for diagnostic records include: Extra and intraoral images to supplement clinical exam, dental casts (or digital 
models), intraoral and/or panoramic radiographs, and lateral cephalometric radiograph to evaluate hard and soft tissue craniofacial structures [14]. The AAO also states that "a CBCT may be used" instead of lateral cephalometric imaging. However, these CBCT recommendations based on a 2008 study by Silva, et al., that was based on adult patients, not pediatric patients [7].

As opposed to its 2D film and digital counterparts, CBCT has allowed for a true representation of the patient in all dimensions [1]. The orthodontist is also able to view information that cannot be viewed in $2 \mathrm{D}$ imaging. In the majority of patients, panoramic and lateral cephalometric radiographs provide adequate information. However, there may be situations in which greater and more accurate information would be beneficial. In many of these situations, select periapicals may provide the orthodontist with the additional information they are seeking [4]. Yet, it is unclear whether the benefits obtained using CBCT imaging for the diagnosis and treatment planning of orthodontic patients outweighs possible risks of ionizing radiation associated with this new imaging modality. As more and more offices are becoming equipped with their own CBCT machines, the specialty must ask itself, "Just because we can subject all of our patients to CBCT imaging, should we be doing so?"

Radiation dosimetry involves determining the amount of radiation exposure to the body $[8,9]$. The dose is the amount of energy absorbed per unit of mass at a particular site of the body. Exposure is a measurement of an X-ray's ability to ionize air under Standard Conditions of Temperature and Pressure (STP). Exposure measures the intensity of radiation, but not the amount of radiation absorbed. When the term "dose" is used, it typically refers to the effective dose. Effective dose is used to estimate the risk of radiation of humans. It allows risk from exposure to one region of the body to be compared with risk from exposure to another region by converting all doses to an equivalent whole-body dose. Dosimetry can be calculated using a tissue equivalent anthropomorphic phantom with Optically Stimulated Luminescent Dosimeters (OSLDs) placed in radiosensitive regions. Then, a number of radiographic exposures can be repeatedly performed using typical exposure factors for the imaging value being investigated. Dosimeters are then read in order to determine the radiation absorbed dose in the individual tissue regions. Equivalent and effective doses can then be calculated using the radiation absorbed dose. Once a dosimeter measures the absorbed dose, it must be converted to equivalent dose and multiplied by a tissue-weighting factor that is defined by the International Commission on Radiological Protection (ICRP) [11,12]. The effective doses of individual tissues can then be summed in order to calculate the total effective dose. This total effective dose is used to quantify the biological risk of ionizing radiation on the whole body. The ICRP has allocated each tissue a numerical value. This numerical value is called a tissueweighting factor based on the tissue's radiosensitivity. The greater the risk that a tissue has of being damaged, the higher this tissue-weighting factor value is. The sum of individual tissue weighting factors is equivalent to the whole-body weighting factor. It is the ICRP's duty to set

Goren AD | Volume 2; Issue 2 (2021) | JDHOR-2(2)-026 | Data Article

Citation: Goren AD, et al. Dosimetry Comparison of CBCT versus Digital 2D Orthodontic Imaging in

a Pediatric Orthodontic Patient. J Dental Health Oral Res. 2021;2(2):1-28.

DOI: http://dx.doi.org/10.46889/JDHOR.2021.2201 
maximum annual dose limits for radiation workers. The recommendations on dose limits by the ICRP include that no practice shall be adopted unless its introduction produces a positive net benefit; that all exposures should be kept as low as reasonably practicable; and that the dose equivalent to individuals shall not exceed the limits recommended by the ICRP.

Radiation can have an impact on biological tissue, and the study of such effects is the field of radiobiology $[4,8,9]$. Radiation-induced tissue damage can include both direct damage that is due to ionization of macromolecules and indirect damage that is a result of free radicals produced by water ionization. Although it is difficult to estimate actual risk in humans of developing cancer from dental radiography, the ICRP has made estimates that a full mouth series of X-rays given to 1-million people would cause two additional cancer deaths over the lifetimes of the 1-million people.

As a healthcare provider, orthodontists must be able to discuss with patients risks and benefits related to using X-rays. Certain precautions are taken by all dentists in order to reduce hazards to patients. The three main principles in reducing dental exposure include the principles of justification, optimization, and dose limitation. The benefit of taking radiographs must always outweigh any potential harm. ALARA, or "As Low As Reasonably Achievable", means that a clinician should only expose a patient the minimum amount of radiation that achieves a direct benefit [5]. Lastly, dose limits are put in place to make sure that people are not exposed to unreasonably high levels of radiation, whether occupationally or the public.

In 2013, the American Academy of Oral and Maxillofacial Radiology (AAOMR) has made clinical recommendations on the use of CBCT imaging in orthodontics, but no legally binding regulations in orthodontics exist [4,12]. The AAOMR statement was made by a group of board certified orthodontists and maxillofacial radiologists with the goals of both reviewing current science on the benefits of CBCT in orthodontics and developing orthodontic-specific clinical guidelines [12]. The group ultimately concluded that "there is no clear evidence to support the routine use of ionizing radiation in standard orthodontic diagnosis and treatment planning, including the use of CBCT." However, the group suggested these guidelines for the use of CBCT in orthodontics:

1. Image appropriately according to clinical condition

2. Assess the radiation dose risk

3. Minimize patient radiation exposure

4. Maintain professional competency in performing and interpreting CBCT studies [12]

Clinicians make a judgement based on the clinical examination and the ALARA principle. The Centers for Disease Control states that "even if it is a small dose, if receiving that dose has no direct benefit, you should try to avoid it." In orthodontics, where children represent the greatest population treated, practitioners must be most cautious in their adherence to ALARA. The

Goren AD | Volume 2; Issue 2 (2021) | JDHOR-2(2)-026 | Data Article

Citation: Goren AD, et al. Dosimetry Comparison of CBCT versus Digital 2D Orthodontic Imaging in

a Pediatric Orthodontic Patient. J Dental Health Oral Res. 2021;2(2):1-28.

DOI: http://dx.doi.org/10.46889/JDHOR.2021.2201 
decision to take a radiograph in orthodontics is only considered after reviewing the patient's chief complaint, taking a proper medical and dental history, needing additional information to properly diagnose, or in order to monitor treatment and treatment outcomes [4]. The use of rectangular collimation in dentistry can reduce radiation dose by five times [8]. In orthodontics, where panoramic, cephalometric, or CBCT imaging is used rather than intraoral imaging, lead aprons and collars are essential in reducing radiation exposure. Thyroid collars are recommended by the American Dental Association in children, who represent typical orthodontic patients-as they are particularly vulnerable to the effects of radiation. A study by Goren, et al., evaluated the effectiveness of leaded glasses and lead thyroid collars on reducing radiation doses during CBCT imaging [13]. The group used an adult female phantom and determined that there was a $74 \%$ reduction in dose to the internal eye, a $61 \%$ reduction to the eye lens, and $42 \%$ reduction to the thyroid when using lead glasses and thyroid shields. Lastly, the group found that collimation alone reduced dose to the brain by $91 \%$. Based on these results, it was concluded that leaded glasses, thyroid collars, and collimation are all ways to reduce dose to patient's organs that are not being imaged.

To date, no studies have been performed using a 10-year-old pediatric anthropomorphic phantom to compare the dosimetry of CBCT imaging versus 2D digital lateral cephalometric and panoramic imaging. The 10-year-old pediatric phantom more closely represents the typical age at which an orthodontic patient presents to the orthodontist than a young adult phantom or an adult phantom. Several studies have compared CBCT dosimetry to digital 2D imaging using adult phantoms. In a study by Ludlow et al. in 2003, the group determined the effective dose measurements for two extraoral digital imaging devices (NewTom 9000 CBCT unit and Orthophos Plus DS Panoramic Unit) [14]. Thermoluminescent dosimeter chips were placed at 20 sites throughout the head and neck of an adult RANDO phantom, which is constructed with natural human skeleton inside. They then performed a combined maxillary and mandibular scan, a maxillary scan, and a mandibular scan using CBCT. Panoramic imaging was used as a control in this study to compare to the CBCT imaging dosimetry results. The group determined that the effective doses for the CBCT imaging were 3-7 (EICRP60) times and 2-4 (ESAL) times higher than the panoramic doses recorded.

The Ludlow group's 2006 study compared the dosimetries of 3 CBCT machines (CB Mercurary, NewTom 3G and i-CAT) with digital panoramic imaging in an adult RANDO phantom [15]. Just as in the previous study, the group placed TLD chips at various locations of the adult head and neck. Each of the three CBCT units were run using the large field of view, which allowed for analyzing both maxillofacial anatomy and the skull base. The large field of view could be used for orthodontic diagnosis and treatment planning, unlike small field of view CBCT imaging. This study found that CBCT imaging doses were 4 to 42 times greater than the doses measured for $2 \mathrm{D}$ digital panoramic imaging. The group noted that the various

Goren AD | Volume 2; Issue 2 (2021) | JDHOR-2(2)-026 | Data Article

Citation: Goren AD, et al. Dosimetry Comparison of CBCT versus Digital 2D Orthodontic Imaging in

a Pediatric Orthodontic Patient. J Dental Health Oral Res. 2021;2(2):1-28.

DOI: http://dx.doi.org/10.46889/JDHOR.2021.2201 
machines had different recommended exposure settings and thus had large variations in amount of exposure recorded.

In 2008, Silva, et al., compared radiation doses of digital panoramic and cephalometric imaging to doses from two CBCT machines, as well as a CT machine [15-18]. The anthropomorphic phantom was developed at the University of Gottingen and was not specifically representative of a pediatric patient. The CBCT machines used were the NewTom 9000 (QR, Verona, Italy), the i-CAT (Imaging Sciences International, Hatfield, PA), the Panoramic and lateral cephalometric Orthophos Plus DS (Sirona Dental Systems, Bernsheim, Germany), and the multi-slice CT (Somatom Sensation 65; Siemens Medical Solutions, Erlangen, Germany). Young male adult exposure settings were used for the Panoramic and multi-slice CT, but automatic settings were used for the NewTom and i-CAT machines. The group found that the effective dose was lower for the panoramic and lateral cephalometric machines than in multislice CT and CBCT imaging. The group determined that while conventional 2D imaging produce the lowest doses, CBCT imaging produced smaller doses than multi-slice CT imaging.

Grunheid, et al., 2012 study compared doses from the i-CAT CBCT (Imaging Sciences International, Hatfield, PA) at different settings to the orthopantomograph OP 100/OC100 digital panoramic and cephalometric machine (Instrumentarium Dental, Tuusula, Finland) [17]. The group used an adult male RANDO anthropomorphic phantom. The group found that CBCT imaging produced significantly higher radiation doses than 2D digital panoramic and lateral cephalometric imaging. For standard resolution CBCT imaging, the dose ranged from 64.7 to $69 \mu \mathrm{Sv}$. Higher doses were recorded with higher resolution settings and larger field of views, as shown in other studies. For digital panoramic imaging, the effective dose was measured at $21.5 \mu \mathrm{Sv}$, while an effective dose measurement of $4.5 \mu \mathrm{Sv}$ was determined for digital lateral cephalometric imaging. In agreeance with other studies discussed, the Grunheid group concluded that CBCT imaging exposes patients to higher levels of radiation despite some diagnostic benefits that it may have.

Previous studies have compared adult versus pediatric phantom CBCT dosimetry. In a study from 2013 by Ludlow's group, they addressed the shortcomings of their previous studies that focused solely on adult anthropomorphic phantoms [16]. The group evaluated doses of different field of view sizes, locations, and exposures of both pediatric and adult phantom heads using the i-CAT FLX unit (Imaging Sciences, Hatfield, PA). They included the QuickScan and QuickScan ${ }^{+}$exposure settings, which were a lower dose but lower resolution setting. The group was able to evaluate the image contrast-to-noise ratio as a means of measuring image quality. At the time, the QuickScan ${ }^{+}$protocols were brand new, and the group found that by reducing emergency and milliampers with this setting, they were able to greatly reduce dosimetry while only modestly reducing image quality [16]. In fact, the group determined that the QuickScan ${ }^{+}$ effective dose measurements were similar to those of 2D digital panoramic imaging using data

Goren AD | Volume 2; Issue 2 (2021) | JDHOR-2(2)-026 | Data Article

Citation: Goren AD, et al. Dosimetry Comparison of CBCT versus Digital 2D Orthodontic Imaging in

a Pediatric Orthodontic Patient. J Dental Health Oral Res. 2021;2(2):1-28.

DOI: http://dx.doi.org/10.46889/JDHOR.2021.2201 
obtained from previous studies. It is important to note that the group found a $36 \%$ greater effective dose reading in the pediatric phantom versus the adult phantom, demonstrating that children may be more vulnerable to the effects of radiation exposure.

Al Najjar, et al., 2013 study sought to compare the differences in measured doses during CBCT between pediatric and adult anthropomorphic phantoms [19]. The phantom heads used corresponded to a 33-year-old woman and a 5-year-old boy. The group used both the i-Cat Platinum CBCT (Imaging Sciences International, Hatfield, PA) and the Iluma CBCT (IMTEC, Ardmore, Okla). For the i-CAT, the group used 5 manufacturer predefined exposure settings, and for the Iluma CBCT, 4 predefined settings were used. The Iluma had pediatric settings available, while the i-CAT did not. As a result, the i-CAT produced greater equivalent doses to children than in adults as compared with the Iluma's pediatric settings. When the pediatric phantom was imaged using adult settings, the equivalent doses measured were significantly higher in children than in adults measured with the same settings. The group found that when similar exposure settings were used, children received greater equivalent dose levels than adults.

\section{Hypothesis}

In the present study, it was hypothesized that the radiation dose of a full-head CBCT is greater than doses received individually from digital panoramic and lateral cephalometric imaging in a pediatric patient when using the same imaging machine. Our aim was to measure and compare the radiation doses absorbed by various head and neck structures in a typical orthodontic patient during CBCT, digital panoramic, and digital lateral cephalometric imaging using the same machine. The ultimate goal of the study was to help support clinical recommendations for the use of CBCT imaging during orthodontic diagnosis and treatment planning of pediatric patients.

\section{Materials and Methods}

A pediatric CIRS anthropomorphic phantom head corresponding to a 10-year-old male patient $140 \mathrm{~cm}$ in height and $32 \mathrm{~kg}$ in weight was used in this study (model 706; Computerized Imaging Reference System, Norfolk, Va) (Fig. 1).

Doses were investigated using the Instrumentarium Orthopantomograph OP300 Maxio using the machine's whole-head CBCT, panoramic, and lateral cephalometric imaging capabilities using the manufacture's predefined exposure settings (Instrumentarium Dental, Tuusula, Finland). Table 1 shows the parameters for each imaging technique. Prior to each set of runs, a scout image was taken using the phantom to ensure proper positioning of the phantom in the

Goren AD | Volume 2; Issue 2 (2021) | JDHOR-2(2)-026 | Data Article

Citation: Goren AD, et al. Dosimetry Comparison of CBCT versus Digital 2D Orthodontic Imaging in

a Pediatric Orthodontic Patient. J Dental Health Oral Res. 2021;2(2):1-28.

DOI: http://dx.doi.org/10.46889/JDHOR.2021.2201 
machine and to confirm that the region of interest was in the field of view (Fig. 2). Unexposed control dosimeters were kept outside the imaging room to establish an average background radiation dose that was later subtracted from the test dosimeters. Radiation doses were measured using OSL dosimeters (Nanodot; Landauer, Glenwood, Ill) (Fig. 1). The dosimeters were placed at various radiosensitive head and neck positions representing organs from the level of the cranium to the clavicle (Table 2). All imaging was repeated by the same investigator.

Beginning with run 1 of the whole-head CBCT, twenty OSLDs were placed at twenty different locations in the phantom head. For each imaging protocol, three exposures were used to allow for a more reliable measurement. When the dosimeters were later analyzed, the doses were divided by 3 and subtracted by the average background radiation serving as a control to determine each exposure per scan for the individual OSLDs. After the first run using twenty OSLDs, runs 2-11 were performed using OSLD chips placed at the thyroid only. A Monte Carlo Analysis was performed to extrapolate the absorbed doses for the remaining twenty organ locations for runs 2 through 11. Equivalent doses for 11 radiosensitive head and neck organs and overall effective doses for each of the 33 total runs was determined using the International Commission on Radiological Protection's (ICRP) tissue weighting factor guidelines. This protocol was repeated for digital panoramic and lateral cephalometric imaging. A Monte Carlo Simulation was used to extrapolate the equivalent dose for the lens of the eye for each of the 33 runs. All statistical evaluations were performed using SPSS (IBM, Armonk, NY).

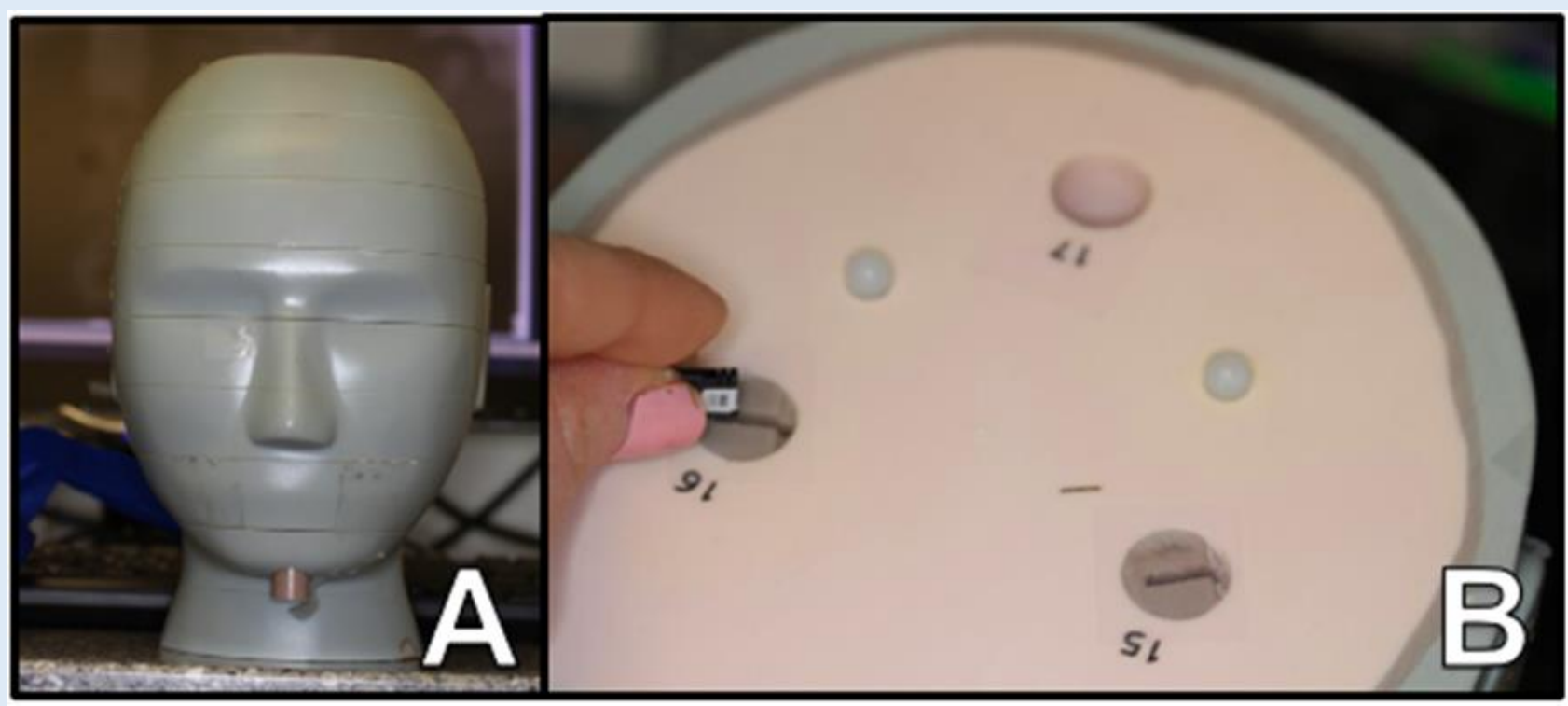

Figure 1: (A) CIRS Atom $\mu$ Dosimetry Verification Phantom, 10-year old. (B) Placement of OSLD into grid holes in phantom axial slice.

Goren AD | Volume 2; Issue 2 (2021) | JDHOR-2(2)-026 | Data Article

Citation: Goren AD, et al. Dosimetry Comparison of CBCT versus Digital 2D Orthodontic Imaging in a Pediatric Orthodontic Patient. J Dental Health Oral Res. 2021;2(2):1-28. 


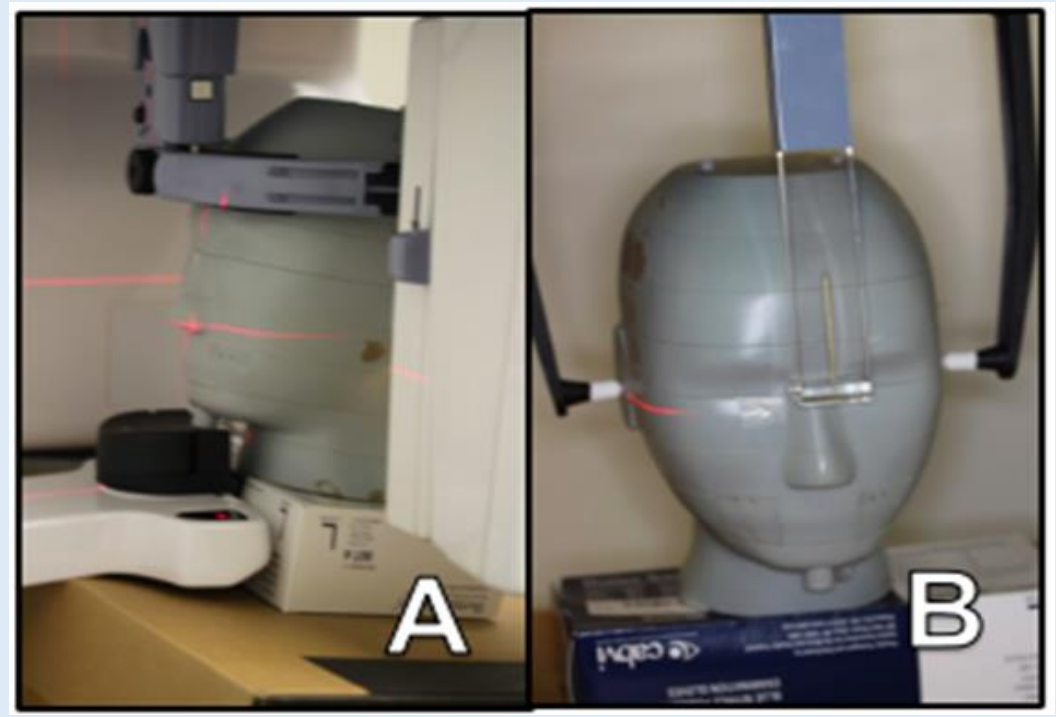

Figure 2: Set up of a 10-year-old anthropomorphic phantom in the instrumentarium OP300 during (A) whole-head CBCT and panoramic imaging (B) lateral cephalometric imaging.

\begin{tabular}{|c|c|c|c|}
\hline & $\begin{array}{c}\text { Exposure time } \\
\text { Type of Scan }\end{array}$ & $\begin{array}{c}\text { Kilovoltage } \\
(\mathbf{k V})\end{array}$ & Current (mA) \\
\hline $\begin{array}{c}\text { Whole-head } \\
\text { CBCT } \\
\text { (13xl5cm) }\end{array}$ & 4.5 & 90 & 3.2 \\
\hline Panoramic & 16 & 66 & 10.0 \\
\hline Lateral Ceph & 16 & 90 & 12.5 \\
\hline
\end{tabular}

Table 1: Exposure settings for the instrumentarium OP300. 


\begin{tabular}{|l|l|}
\hline OSLD No. & 10-year-old Phantom Location \\
\hline $\mathbf{1}$ & Bone Marrow \\
\hline $\mathbf{2}$ & Mandible \\
\hline $\mathbf{3}$ & Calvarium \\
\hline $\mathbf{5}$ & Cervical Spine \\
\hline $\mathbf{6}$ & Thyroid \\
\hline $\mathbf{7}$ & Esophagus \\
\hline $\mathbf{8}$ & Bkin \\
\hline $\mathbf{9}$ & Mandible \\
\hline $\mathbf{1 0}$ & Calvarium \\
\hline $\mathbf{1 1}$ & Cervical Spine \\
\hline $\mathbf{1 2}$ & Salivary Glands \\
\hline $\mathbf{1 3}$ & Parotid \\
\hline $\mathbf{1 4}$ & Submandibular \\
\hline $\mathbf{1 5}$ & Sublingual \\
\hline $\mathbf{1 6}$ & Brain \\
\hline $\mathbf{1 7}$ & Lymphatic Nodes \\
\hline $\mathbf{1 8}$ & Muscle \\
\hline $\mathbf{1 9}$ & Extrathoracic Airway \\
\hline $\mathbf{2 0}$ & Oral Mucosa \\
\hline $\mathbf{2}$ & \\
\hline
\end{tabular}

Table 2: OSL dosimeter locations in a ten-year-old phantom.

\section{Results}

The absorbed ( $\mu \mathrm{Gy})$ and equivalent $(\mu \mathrm{Sv})$ organ doses across the three imaging modalities for the pediatric phantom is presented in Table 3. The average value was obtained from the 11 runs for each imaging modality. The cervical spine received the lowest absorbed organ dose $(4.11 \mu \mathrm{Gy})$ during whole-head $\mathrm{CBCT}$, while the lymphatic nodes and muscle received the lowest equivalent dose during whole-head CBCT $(0.15 \mu \mathrm{Gy})$. The lowest absorbed dose during panoramic imaging was in the calvarium $(1.42 \mu \mathrm{Gy})$, but the skin received the lowest equivalent dose during this modality $(0.07 \mu \mathrm{Gy})$. For lateral cephalometric imaging, the mandible received the lowest absorbed dose $(0.78 \mu \mathrm{Gy})$ and the lymphatic nodes and muscle received the lowest equivalent dose $(0.03 \mu \mathrm{Gy})$. Consistent with previous studies, the salivary glands received the highest absorbed and effective doses across the three different imaging modalities [17]. 
A log transformation of the absorbed and equivalent dose values was performed in order to correct for heterogeneity of variance. A Levene's Test was performed in order to confirm homogeneity of variance ( $p>0.05$ ) (Table 4). The non-significant finding for this test confirmed that the Analysis of Variance (ANOVA) assumptions were not violated and that it provided accurate results. An ANOVA was used to determine whether there were significant differences in the absorbed doses and equivalent doses across the three imaging modalities for each organ (Table 5 and 6). Significant differences were found across all organs for both absorbed and equivalent doses. A multiple comparisons test was performed for absorbed and equivalent doses to determine which of the three imaging modalities were significantly different from each other (Table 6-11). All of the imaging modalities showed statistically significant differences to one another for all absorbed organ doses except for the cervical spine. For the cervical spine, there was not a statistically significant difference in the absorbed doses measured for the panoramic and lateral cephalometric radiographs ( $p>0.05)$. Equivalent doses were statistically significantly different for every organ across the three imaging modalities. The values for the effective doses are given in Table 10 and Fig. 3-5. The highest value was for the whole-head CBCT $(33.9 \mu \mathrm{Sv})$, followed by the panoramic $(15.6 \mu \mathrm{Sv})$, and then the lateral cephalometric $(8.1 \mu \mathrm{Sv})$. The whole-head CBCT therefore produced an effective dose that was $43 \%$ greater than the combined effective doses of the panoramic and lateral cephalometric radiographs $(23.7 \mu \mathrm{Sv})$.

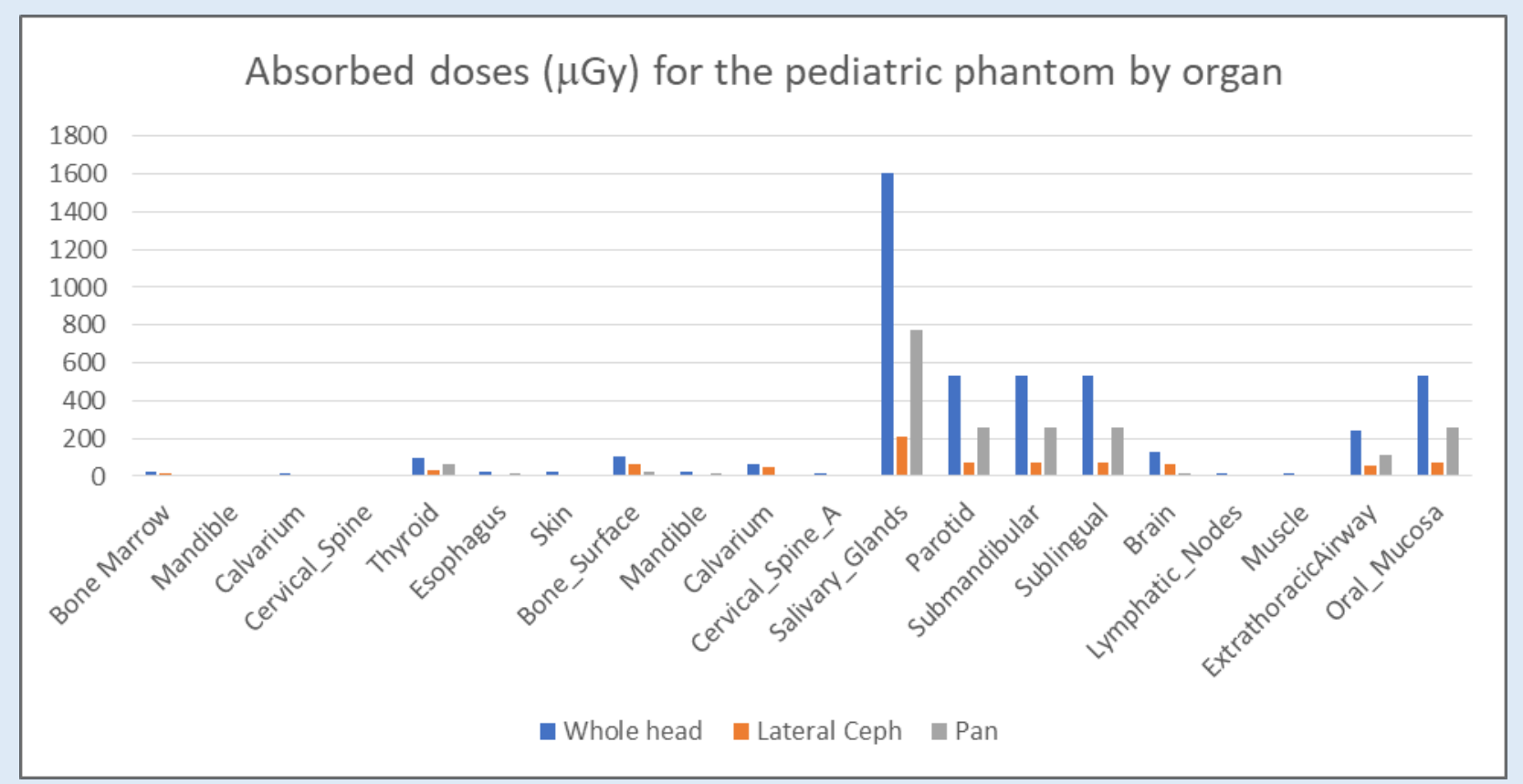

Figure 3: Absorbed doses ( $\mu \mathrm{Gy}$ ) for the pediatric phantom by organ. The lowest absorbed doses for the whole-head CBCT was at the cervical spine $(4.11 \mu \mathrm{Gy})$. The lowest absorbed dose for panoramic imaging was at the calvarium $(1.42 \mu \mathrm{Gy})$. The lowest absorbed dose for

lateral cephalometric was at the mandible $(0.78 \mu \mathrm{Gy})$. The salivary glands received the highest absorbed doses across the three different imaging modalities.

Goren AD | Volume 2; Issue 2 (2021) | JDHOR-2(2)-026 | Data Article

Citation: Goren AD, et al. Dosimetry Comparison of CBCT versus Digital 2D Orthodontic Imaging in a Pediatric Orthodontic Patient. J Dental Health Oral Res. 2021;2(2):1-28. 


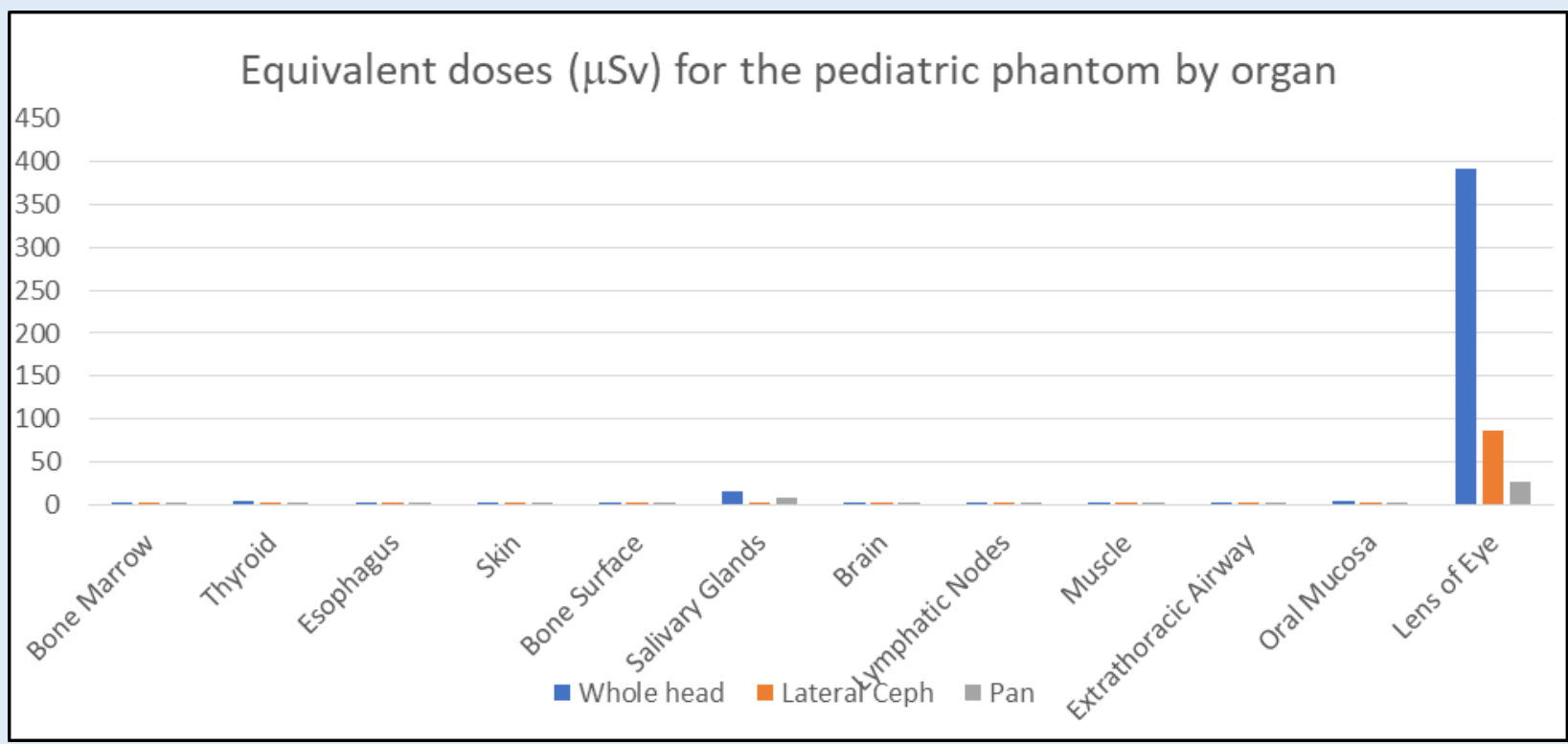

Figure 4: Equivalent doses $(\mu \mathrm{Sv})$ for the pediatric phantom by organ. The lowest equivalent doses for the whole-head CBCT and lateral ceph were at the lymphatic nodes and muscles $(0.15 \mu \mathrm{Gy}$ and $0.03 \mu \mathrm{Gy}$, respectively). For panoramic imaging, the lowest equivalent dose was at the skin $(0.07 \mu \mathrm{Gy})$. The Salivary gland and lens of eye received the highest equivalent doses.

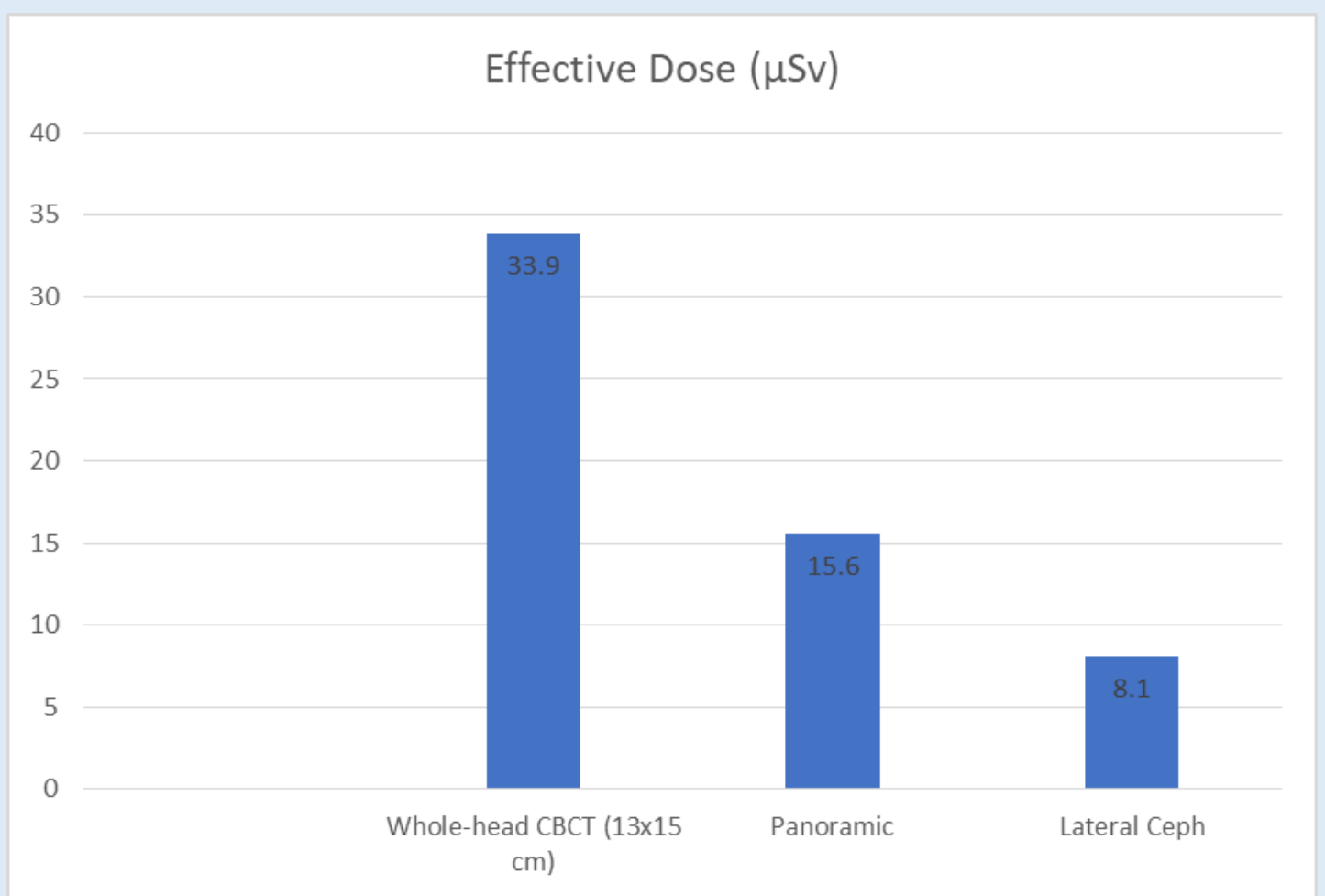

Figure 5: Average effective doses across imaging modalities. 


\begin{tabular}{|c|c|c|c|c|c|c|}
\hline \multicolumn{7}{|c|}{ Descriptives } \\
\hline & & $\mathrm{N}$ & Mean & Std. Deviation & Minimum & Maximum \\
\hline \multirow[t]{4}{*}{ Bone_Marrow } & whole head & 11 & 25.04 & 3.68 & 17.42 & 29.74 \\
\hline & lateral ceph & 11 & 14.63 & 1.74 & 12.13 & 17.62 \\
\hline & pan & 11 & 6.44 & .81 & 5.53 & 8.53 \\
\hline & Total & 33 & 15.37 & 8.07 & 5.53 & 29.74 \\
\hline \multirow[t]{4}{*}{ Mandible } & whole head & 11 & 5.88 & 1.06 & 3.26 & 7.03 \\
\hline & lateral ceph & 11 & .78 & .10 & .64 & .95 \\
\hline & pan & 11 & 2.83 & .27 & 2.52 & 3.54 \\
\hline & Total & 33 & 3.16 & 2.22 & .64 & 7.03 \\
\hline \multirow[t]{4}{*}{ Calvarium } & whole head & 11 & 15.04 & 2.09 & 11.10 & 17.84 \\
\hline & lateral ceph & 11 & 11.71 & 1.38 & 9.73 & 14.08 \\
\hline & pan & 11 & 1.42 & .30 & 1.09 & 2.18 \\
\hline & Total & 33 & 9.39 & 6.05 & 1.09 & 17.84 \\
\hline \multirow[t]{4}{*}{ Cervical_Spine } & whole head & 11 & 4.11 & .56 & 3.05 & 4.87 \\
\hline & lateral ceph & 11 & 2.14 & .26 & 1.76 & 2.59 \\
\hline & pan & 11 & 2.19 & .24 & 1.92 & 2.81 \\
\hline & Total & 33 & 2.81 & 1.00 & 1.76 & 4.87 \\
\hline \multirow[t]{4}{*}{ Thyroid } & whole head & 11 & 99.81 & 13.83 & 75.29 & 118.70 \\
\hline & lateral ceph & 11 & 35.31 & 5.20 & 27.87 & 44.26 \\
\hline & pan & 11 & 62.94 & 7.13 & 55.00 & 81.25 \\
\hline & Total & 33 & 66.02 & 28.35 & 27.87 & 118.70 \\
\hline \multirow[t]{4}{*}{ Esophagus } & whole head & 11 & 19.96 & 2.77 & 15.06 & 23.74 \\
\hline & lateral ceph & 11 & 7.06 & 1.04 & 5.57 & 8.85 \\
\hline & pan & 11 & 12.59 & 1.43 & 11.00 & 16.25 \\
\hline & Total & 33 & 13.20 & 5.67 & 5.57 & 23.74 \\
\hline \multirow[t]{4}{*}{ Skin } & whole head & 11 & 23.18 & 3.63 & 14.84 & 27.48 \\
\hline & lateral ceph & 11 & 3.95 & .48 & 3.25 & 4.78 \\
\hline & pan & 11 & 7.09 & .72 & 6.29 & 8.95 \\
\hline & Total & 33 & 11.41 & 8.81 & 3.25 & 27.48 \\
\hline \multirow[t]{4}{*}{ Bone_Surface } & whole head & 11 & 104.67 & 15.39 & 72.80 & 124.30 \\
\hline & lateral ceph & 11 & 61.14 & 7.27 & 50.71 & 73.63 \\
\hline & pan & 11 & 26.94 & 3.39 & 23.11 & 35.64 \\
\hline & Total & 33 & 64.25 & 33.73 & 23.11 & 124.30 \\
\hline \multirow[t]{4}{*}{ Mandible } & whole head & 11 & 24.60 & 4.41 & 13.65 & 29.38 \\
\hline & lateral ceph & 11 & 3.26 & .41 & 2.67 & 3.95 \\
\hline & pan & 11 & 11.83 & 1.15 & 10.55 & 14.80 \\
\hline & Total & 33 & 13.23 & 9.26 & 2.67 & 29.38 \\
\hline \multirow[t]{4}{*}{ Calvarium } & whole head & 11 & 62.88 & 8.75 & 46.40 & 74.57 \\
\hline & lateral ceph & 11 & 48.94 & 5.77 & 40.67 & 58.86 \\
\hline & pan & 11 & 5.94 & 1.23 & 4.55 & 9.11 \\
\hline & Total & 33 & 39.25 & 25.30 & 4.55 & 74.57 \\
\hline
\end{tabular}

Goren AD | Volume 2; Issue 2 (2021) | JDHOR-2(2)-026 | Data Article

Citation: Goren AD, et al. Dosimetry Comparison of CBCT versus Digital 2D Orthodontic Imaging in a Pediatric Orthodontic Patient. J Dental Health Oral Res. 2021;2(2):1-28. 


\begin{tabular}{|c|c|c|c|c|c|c|}
\hline \multicolumn{7}{|c|}{ Descriptives } \\
\hline & & $\mathrm{N}$ & Mean & Std. Deviation & Minimum & Maximum \\
\hline \multirow[t]{4}{*}{ Romo_Marrom } & 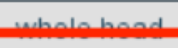 & 14 & 2504 & 3.68 & 17.42 & 29.74 \\
\hline & lateral ceph & 11 & 14.63 & 1.74 & 12.13 & 17.62 \\
\hline & pan & 11 & 6.44 & .81 & 5.53 & 8.53 \\
\hline & Total & 33 & T5.37 & 8.07 & 5.53 & 29.74 \\
\hline \multirow[t]{4}{*}{ Mandible } & whole head & 11 & 5.88 & 1.06 & 3.26 & 7.03 \\
\hline & lateral ceph & 11 & .78 & .10 & .64 & .95 \\
\hline & pan & 11 & 2.83 & .27 & 2.52 & 3.54 \\
\hline & Total & 33 & 3.16 & 2.22 & .64 & 7.03 \\
\hline \multirow[t]{4}{*}{ Calvarium } & whole head & 11 & 15.04 & 2.09 & 11.10 & 17.84 \\
\hline & lateral ceph & 11 & 11.71 & 1.38 & 9.73 & 14.08 \\
\hline & pan & 11 & 1.42 & .30 & 1.09 & 2.18 \\
\hline & Total & 33 & 9.39 & 6.05 & 1.09 & 17.84 \\
\hline \multirow[t]{4}{*}{ Cervical_Spine } & whole head & 11 & 4.11 & .56 & 3.05 & 4.87 \\
\hline & lateral ceph & 11 & 2.14 & .26 & 1.76 & 2.59 \\
\hline & pan & 11 & 2.19 & .24 & 1.92 & 2.81 \\
\hline & Total & 33 & 2.81 & 1.00 & 1.76 & 4.87 \\
\hline \multirow[t]{4}{*}{ Thyroid } & whole head & 11 & 99.81 & 13.83 & 75.29 & 118.70 \\
\hline & lateral ceph & 11 & 35.31 & 5.20 & 27.87 & 44.26 \\
\hline & pan & 11 & 62.94 & 7.13 & 55.00 & 81.25 \\
\hline & Total & 33 & 66.02 & 28.35 & 27.87 & 118.70 \\
\hline \multirow[t]{4}{*}{ Esophagus } & whole head & 11 & 19.96 & 2.77 & 15.06 & 23.74 \\
\hline & lateral ceph & 11 & 7.06 & 1.04 & 5.57 & 8.85 \\
\hline & pan & 11 & 12.59 & 1.43 & 11.00 & 16.25 \\
\hline & Total & 33 & 13.20 & 5.67 & 5.57 & 23.74 \\
\hline \multirow[t]{4}{*}{ Skin } & whole head & 11 & 23.18 & 3.63 & 14.84 & 27.48 \\
\hline & lateral ceph & 11 & 3.95 & .48 & 3.25 & 4.78 \\
\hline & pan & 11 & 7.09 & .72 & 6.29 & 8.95 \\
\hline & Total & 33 & 11.41 & 8.81 & 3.25 & 27.48 \\
\hline \multirow[t]{4}{*}{ Bone_Surface } & whole head & 11 & 104.67 & 15.39 & 72.80 & 124.30 \\
\hline & lateral ceph & 11 & 61.14 & 7.27 & 50.71 & 73.63 \\
\hline & pan & 11 & 26.94 & 3.39 & 23.11 & 35.64 \\
\hline & Total & 33 & 64.25 & 33.73 & 23.11 & 124.30 \\
\hline \multirow[t]{4}{*}{ Mandible } & whole head & 11 & 24.60 & 4.41 & 13.65 & 29.38 \\
\hline & lateral ceph & 11 & 3.26 & .41 & 2.67 & 3.95 \\
\hline & pan & 11 & 11.83 & 1.15 & 10.55 & 14.80 \\
\hline & Total & 33 & 13.23 & 9.26 & 2.67 & 29.38 \\
\hline Calvarium & whole head & 11 & 6288 & 875 & 4640 & 7457 \\
\hline
\end{tabular}

Table 3: Absorbed doses ( $\mu \mathrm{Gy})$ for the pediatric phantom by organ.

Goren AD | Volume 2; Issue 2 (2021) | JDHOR-2(2)-026 | Data Article

Citation: Goren AD, et al. Dosimetry Comparison of CBCT versus Digital 2D Orthodontic Imaging in a Pediatric Orthodontic Patient. J Dental Health Oral Res. 2021;2(2):1-28. 
Test of Homogeneity of Variances

\begin{tabular}{|c|c|c|c|c|c|}
\hline \multicolumn{6}{|c|}{ Test of Homogeneity of Variances } \\
\hline & & $\begin{array}{l}\text { Levene } \\
\text { Statistic }\end{array}$ & df1 & df2 & Sig. \\
\hline \multirow[t]{4}{*}{ Bone Marrow } & Based on Mean & .696 & 2 & 30 & .506 \\
\hline & Based on Median & .679 & 2 & 30 & .515 \\
\hline & $\begin{array}{l}\text { Based on Median and } \\
\text { with adjusted df }\end{array}$ & .679 & 2 & 29.330 & .515 \\
\hline & Based on trimmed mean & .659 & 2 & 30 & .525 \\
\hline \multirow[t]{4}{*}{ Mandible } & Based on Mean & 1.459 & 2 & 30 & .248 \\
\hline & Based on Median & 1.242 & 2 & 30 & .303 \\
\hline & $\begin{array}{l}\text { Based on Median and } \\
\text { with adjusted df }\end{array}$ & 1.242 & 2 & 18.989 & .311 \\
\hline & Based on trimmed mean & 1.267 & 2 & 30 & .296 \\
\hline \multirow[t]{4}{*}{ Calvarium } & Based on Mean & .661 & 2 & 30 & .524 \\
\hline & Based on Median & .598 & 2 & 30 & .556 \\
\hline & $\begin{array}{l}\text { Based on Median and } \\
\text { with adjusted df }\end{array}$ & .598 & 2 & 23.291 & .558 \\
\hline & Based on trimmed mean & .687 & 2 & 30 & .511 \\
\hline \multirow[t]{4}{*}{ Cervical Spine } & Based on Mean & .815 & 2 & 30 & .452 \\
\hline & Based on Median & .824 & 2 & 30 & .448 \\
\hline & $\begin{array}{l}\text { Based on Median and } \\
\text { with adjusted df }\end{array}$ & .824 & 2 & 29.791 & .448 \\
\hline & Based on trimmed mean & .817 & 2 & 30 & .451 \\
\hline \multirow[t]{4}{*}{ Thyroid } & Based on Mean & .751 & 2 & 30 & .481 \\
\hline & Based on Median & .746 & 2 & 30 & .483 \\
\hline & $\begin{array}{l}\text { Based on Median and } \\
\text { with adjusted df }\end{array}$ & .746 & 2 & 28.011 & .484 \\
\hline & Based on trimmed mean & .745 & 2 & 30 & .483 \\
\hline \multirow[t]{4}{*}{ Esophagus } & Based on Mean & .751 & 2 & 30 & .481 \\
\hline & Based on Median & .746 & 2 & 30 & .483 \\
\hline & $\begin{array}{l}\text { Based on Median and } \\
\text { with adjusted df }\end{array}$ & .746 & 2 & 28.011 & .484 \\
\hline & Based on trimmed mean & .745 & 2 & 30 & .483 \\
\hline \multirow[t]{4}{*}{ Skin } & Based on Mean & 1.197 & 2 & 30 & .316 \\
\hline & Based on Median & 1.120 & 2 & 30 & .340 \\
\hline & $\begin{array}{l}\text { Based on Median and } \\
\text { with adjusted df }\end{array}$ & 1.120 & 2 & 24.752 & .342 \\
\hline & Based on trimmed mean & 1.101 & 2 & 30 & .346 \\
\hline \multirow[t]{4}{*}{ Bone Surface } & Based on Mean & .696 & 2 & 30 & .506 \\
\hline & Based on Median & .679 & 2 & 30 & .515 \\
\hline & $\begin{array}{l}\text { Based on Median and } \\
\text { with adjusted df }\end{array}$ & .679 & 2 & 29.330 & .515 \\
\hline & Based on trimmed mean & .659 & 2 & 30 & .525 \\
\hline \multirow[t]{4}{*}{ Mandible } & Based on Mean & 1.459 & 2 & 30 & .248 \\
\hline & Based on Median & 1.242 & 2 & 30 & .303 \\
\hline & $\begin{array}{l}\text { Based on Median and } \\
\text { with adjusted df }\end{array}$ & 1.242 & 2 & 18.989 & .311 \\
\hline & Based on trimmed mean & 1.267 & 2 & 30 & .296 \\
\hline \multirow[t]{4}{*}{ Calvarium } & Based on Mean & .661 & 2 & 30 & .524 \\
\hline & Based on Median & .598 & 2 & 30 & .556 \\
\hline & $\begin{array}{l}\text { Based on Median and } \\
\text { with adjusted df }\end{array}$ & .598 & 2 & 23.291 & .558 \\
\hline & Based on trimmed mean & .687 & 2 & 30 & .511 \\
\hline
\end{tabular}

Goren AD | Volume 2; Issue 2 (2021) | JDHOR-2(2)-026 | Data Article

Citation: Goren AD, et al. Dosimetry Comparison of CBCT versus Digital 2D Orthodontic Imaging in a Pediatric Orthodontic Patient. J Dental Health Oral Res. 2021;2(2):1-28. 


\begin{tabular}{|c|c|c|c|c|c|}
\hline \multicolumn{5}{|c|}{ Test of Homogeneity of Variances } & \multirow[b]{2}{*}{ Sig. } \\
\hline & & $\begin{array}{l}\text { Levene } \\
\text { Statistic }\end{array}$ & df1 & $\mathrm{df} 2$ & \\
\hline \multirow[t]{4}{*}{ Bone Marrow } & Based on Mean & .696 & 2 & 30 & .506 \\
\hline & Based on Median & .679 & 2 & 30 & .515 \\
\hline & $\begin{array}{l}\text { Based on Median and } \\
\text { with adjusted df }\end{array}$ & .679 & 2 & 29.330 & .515 \\
\hline & Based on trimmed mean & .659 & 2 & 30 & .525 \\
\hline \multirow[t]{4}{*}{ Mandible } & Based on Mean & 1.459 & 2 & 30 & .248 \\
\hline & Based on Median & 1.242 & 2 & 30 & .303 \\
\hline & $\begin{array}{l}\text { Based on Median and } \\
\text { with adjusted df }\end{array}$ & 1.242 & 2 & 18.989 & .311 \\
\hline & Based on trimmed mean & 1.267 & 2 & 30 & .296 \\
\hline \multirow[t]{4}{*}{ Calvarium } & Based on Mean & .661 & 2 & 30 & .524 \\
\hline & Based on Median & .598 & 2 & 30 & .556 \\
\hline & $\begin{array}{l}\text { Based on Median and } \\
\text { with adjusted df }\end{array}$ & .598 & 2 & 23.291 & .558 \\
\hline & Based on trimmed mean & .687 & 2 & 30 & .511 \\
\hline \multirow[t]{4}{*}{ Cervical Spine } & Based on Mean & .815 & 2 & 30 & .452 \\
\hline & Based on Median & .824 & 2 & 30 & .448 \\
\hline & $\begin{array}{l}\text { Based on Median and } \\
\text { with adjusted df }\end{array}$ & .824 & 2 & 29.791 & .448 \\
\hline & Based on trimmed mean & .817 & 2 & 30 & .451 \\
\hline \multirow[t]{4}{*}{ Thyroid } & Based on Mean & .751 & 2 & 30 & .481 \\
\hline & Based on Median & .746 & 2 & 30 & .483 \\
\hline & $\begin{array}{l}\text { Based on Median and } \\
\text { with adjusted df }\end{array}$ & .746 & 2 & 28.011 & .484 \\
\hline & Based on trimmed mean & .745 & 2 & 30 & .483 \\
\hline \multirow[t]{4}{*}{ Esophagus } & Based on Mean & .751 & 2 & 30 & .481 \\
\hline & Based on Median & .746 & 2 & 30 & .483 \\
\hline & $\begin{array}{l}\text { Based on Median and } \\
\text { with adjusted df }\end{array}$ & .746 & 2 & 28.011 & .484 \\
\hline & Based on trimmed mean & .745 & 2 & 30 & .483 \\
\hline \multirow[t]{4}{*}{ Skin } & Based on Mean & 1.197 & 2 & 30 & .316 \\
\hline & Based on Median & 1.120 & 2 & 30 & .340 \\
\hline & $\begin{array}{l}\text { Based on Median and } \\
\text { with adjusted df }\end{array}$ & 1.120 & 2 & 24.752 & .342 \\
\hline & Based on trimmed mean & 1.101 & 2 & 30 & .346 \\
\hline \multirow[t]{4}{*}{ Bone Surface } & Based on Mean & .696 & 2 & 30 & .506 \\
\hline & Based on Median & .679 & 2 & 30 & .515 \\
\hline & $\begin{array}{l}\text { Based on Median and } \\
\text { with adjusted df }\end{array}$ & .679 & 2 & 29.330 & .515 \\
\hline & Based on trimmed mean & .659 & 2 & 30 & .525 \\
\hline \multirow[t]{4}{*}{ Mandible } & Based on Mean & 1.459 & 2 & 30 & .248 \\
\hline & Based on Median & 1.242 & 2 & 30 & .303 \\
\hline & $\begin{array}{l}\text { Based on Median and } \\
\text { with adjusted df }\end{array}$ & 1.242 & 2 & 18.989 & .311 \\
\hline & Based on trimmed mean & 1.267 & 2 & 30 & .296 \\
\hline \multirow[t]{2}{*}{ Calvarium } & Based on Mean & .661 & 2 & 30 & .524 \\
\hline & Dacad an Madian & 500 & ? & $2 n$ & \\
\hline
\end{tabular}

Table 4: Test of Homogeneity of Variance. A Levene's Test was performed in order to confirm homogeneity of variance $(p>0.05)$ (highlighted in red). The non-significant finding 
for this test confirmed that the analysis of variance (ANOVA) assumptions were not violated and that it provided accurate results.

\begin{tabular}{|c|c|c|c|c|c|c|}
\hline \multicolumn{7}{|c|}{ ANOVA } \\
\hline & & $\begin{array}{l}\text { Sum of } \\
\text { Squares }\end{array}$ & df & Mean Square & $\mathrm{F}$ & Sig. \\
\hline \multirow[t]{3}{*}{ Bone Marrow } & Between Groups & 10.221 & 2 & 5.111 & 293.343 & .000 \\
\hline & Within Groups & .523 & 30 & .017 & & \\
\hline & Total & 10.744 & 32 & & & \\
\hline \multirow[t]{3}{*}{ Mandible } & Between Groups & 22.845 & 2 & 11.423 & 495.927 & .000 \\
\hline & Within Groups & .691 & 30 & .023 & & \\
\hline & Total & 23.536 & 32 & & & \\
\hline \multirow[t]{3}{*}{ Calvarium } & Between Groups & 37.237 & 2 & 18.619 & 790.062 & .000 \\
\hline & Within Groups & .707 & 30 & .024 & & \\
\hline & Total & 37.944 & 32 & & & \\
\hline \multirow[t]{3}{*}{ Cervical Spine } & Between Groups & 2.995 & 2 & 1.498 & 98.542 & .000 \\
\hline & Within Groups & .456 & 30 & .015 & & \\
\hline & Total & 3.451 & 32 & & & \\
\hline \multirow[t]{3}{*}{ Thyroid } & Between Groups & 5.973 & 2 & 2.987 & 169.248 & .000 \\
\hline & Within Groups & .529 & 30 & .018 & & \\
\hline & Total & 6.503 & 32 & & & \\
\hline \multirow[t]{3}{*}{ Esophagus } & Between Groups & 5.973 & 2 & 2.987 & 169.248 & .000 \\
\hline & Within Groups & .529 & 30 & .018 & & \\
\hline & Total & 6.503 & 32 & & & \\
\hline \multirow[t]{3}{*}{ Skin } & Between Groups & 17.762 & 2 & 8.881 & 492.553 & .000 \\
\hline & Within Groups & .541 & 30 & .018 & & \\
\hline & Total & 18.303 & 32 & & & \\
\hline \multirow[t]{3}{*}{ Bone Surface } & Between Groups & 10.221 & 2 & 5.111 & 293.343 & .000 \\
\hline & Within Groups & .523 & 30 & .017 & & \\
\hline & Total & 10.744 & 32 & & & \\
\hline \multirow[t]{3}{*}{ Mandible } & Between Groups & 22.845 & 2 & 11.423 & 495.927 & .000 \\
\hline & Within Groups & .691 & 30 & .023 & & \\
\hline & Total & 23.536 & 32 & & & \\
\hline \multirow[t]{3}{*}{ Calvarium } & Between Groups & 37.237 & 2 & 18.619 & 790.062 & .000 \\
\hline & Within Groups & .707 & 30 & .024 & & \\
\hline & Total & 37.944 & 32 & & & \\
\hline
\end{tabular}

Goren AD | Volume 2; Issue 2 (2021) | JDHOR-2(2)-026 | Data Article

Citation: Goren AD, et al. Dosimetry Comparison of CBCT versus Digital 2D Orthodontic Imaging in a Pediatric Orthodontic Patient. J Dental Health Oral Res. 2021;2(2):1-28. 


\begin{tabular}{|c|c|c|c|c|c|c|}
\hline \multicolumn{6}{|c|}{ ANOVA } & \multirow[b]{2}{*}{ Sig. } \\
\hline & & $\begin{array}{l}\text { Sum of } \\
\text { Squares }\end{array}$ & df & Mean Square & $\mathrm{F}$ & \\
\hline \multirow[t]{3}{*}{ Bone Marrow } & Between Groups & 10.221 & 2 & 5.111 & 293.343 & .000 \\
\hline & Within Groups & .523 & 30 & .017 & & \\
\hline & Total & 10.744 & 32 & & & \\
\hline \multirow[t]{3}{*}{ Mandible } & Between Groups & 22.845 & 2 & 11.423 & 495.927 & .000 \\
\hline & Within Groups & .691 & 30 & .023 & & \\
\hline & Total & 23.536 & 32 & & & \\
\hline \multirow[t]{3}{*}{ Calvarium } & Between Groups & 37.237 & 2 & 18.619 & 790.062 & .000 \\
\hline & Within Groups & .707 & 30 & .024 & & \\
\hline & Total & 37.944 & 32 & & & \\
\hline \multirow[t]{3}{*}{ Cervical Spine } & Between Groups & 2.995 & 2 & 1.498 & 98.542 & .000 \\
\hline & Within Groups & .456 & 30 & .015 & & \\
\hline & Total & 3.451 & 32 & & & \\
\hline \multirow[t]{3}{*}{ Thyroid } & Between Groups & 5.973 & 2 & 2.987 & 169.248 & .000 \\
\hline & Within Groups & .529 & 30 & .018 & & \\
\hline & Total & 6.503 & 32 & & & \\
\hline \multirow[t]{3}{*}{ Esophagus } & Between Groups & 5.973 & 2 & 2.987 & 169.248 & .000 \\
\hline & Within Groups & .529 & 30 & .018 & & \\
\hline & Total & 6.503 & 32 & & & \\
\hline \multirow[t]{3}{*}{ Skin } & Between Groups & 17.762 & 2 & 8.881 & 492.553 & .000 \\
\hline & Within Groups & .541 & 30 & .018 & & \\
\hline & Total & 18.303 & 32 & & & \\
\hline \multirow[t]{3}{*}{ Bone Surface } & Between Groups & 10.221 & 2 & 5.111 & 293.343 & .000 \\
\hline & Within Groups & .523 & 30 & .017 & & \\
\hline & Total & 10.744 & 32 & & & \\
\hline \multirow[t]{3}{*}{ Mandible } & Between Groups & 22.845 & 2 & 11.423 & 495.927 & .000 \\
\hline & Within Groups & .691 & 30 & .023 & & \\
\hline & Total & 23.536 & 32 & & & \\
\hline
\end{tabular}

Table 5: ANOVA for absorbed doses. An ANOVA was used to determine whether there were significant differences in the absorbed doses across the three imaging modalities for each organ. Significant differences were found across all organs (highlighted in red). 


\begin{tabular}{|c|c|c|c|c|c|}
\hline \multicolumn{6}{|c|}{ Multiple Comparisons } \\
\hline Dependent Variable & (i) perspectivee & (J) perspectivee & $\begin{array}{c}\text { Mean } \\
\text { Difference (- } \\
\text { J) }\end{array}$ & Std. Error & Sig. \\
\hline \multirow[t]{6}{*}{ Bone Marrow } & \multirow[t]{2}{*}{ whole head } & lateral ceph & $53^{\circ}$ & .06 & .00 \\
\hline & & panoramic & $1.35^{\circ}$ & .06 & .00 \\
\hline & \multirow[t]{2}{*}{ lateral ceph } & whole head & $-.53^{\circ}$ & .06 & .00 \\
\hline & & panoramic & $.82^{\circ}$ & .06 & .00 \\
\hline & \multirow[t]{2}{*}{ panoramic } & whole head & $-1.35^{\circ}$ & .06 & .00 \\
\hline & & lateral ceph & $-82^{\circ}$ & .06 & .00 \\
\hline \multirow[t]{6}{*}{ Mandible } & \multirow[t]{2}{*}{ whole head } & lateral ceph & $2.01^{\circ}$ & .06 & .00 \\
\hline & & panoramic & $.72^{\circ}$ & .06 & .00 \\
\hline & \multirow{2}{*}{ lateral ceph } & whole head & $-2.01^{\circ}$ & .06 & .00 \\
\hline & & panoramic & $-1.29^{\circ}$ & .06 & .00 \\
\hline & \multirow[t]{2}{*}{ panoramic } & whole head & $.72^{\circ}$ & .06 & .00 \\
\hline & & Iateral ceph & $1.29^{\circ}$ & .06 & .00 \\
\hline Calvarium & whole head & lateral ceph & $.25^{\circ}$ & .07 & .00 \\
\hline & & panoramic & $2.37^{\circ}$ & .07 & .00 \\
\hline & lateral ceph & whole head & $-25^{\circ}$ & .07 & .00 \\
\hline & & panoramic & $2.12^{\circ}$ & .07 & .00 \\
\hline & panoramic & whole head & $-2.37^{\circ}$ & .07 & .00 \\
\hline & & lateral ceph & $-2.12^{\circ}$ & .07 & .00 \\
\hline Cenvical Spine & whole head & Iateral ceph & $.65^{\circ}$ & .05 & .00 \\
\hline & & panoramic & $.63^{\circ}$ & .05 & .00 \\
\hline & lateral ceph & whole head & -.65 & .05 & .00 \\
\hline & & panoramic & .03 & .05 & 1.00 \\
\hline & panoramic & whole head & $-.63^{\circ}$ & .05 & .00 \\
\hline & & lateral ceph & .03 & .05 & 1.00 \\
\hline Thyroid & whole head & lateral ceph & 1.04 & .06 & .00 \\
\hline & & panoramic & $.46^{\circ}$ & .06 & .00 \\
\hline & lateral ceph & whole head & $-1.04^{\circ}$ & .06 & .00 \\
\hline & & panoramic & $.58^{\circ}$ & .06 & .00 \\
\hline & panoramic & whole head & $-46^{\circ}$ & .06 & .00 \\
\hline & & lateral ceph & $.58^{\circ}$ & .06 & .00 \\
\hline Esophagus & whole head & lateral ceph & $1.04^{\circ}$ & .06 & .00 \\
\hline & & panoramic & $46^{\circ}$ & .06 & .00 \\
\hline & lateral ceph & whole head & $-1.04^{\circ}$ & .06 & .00 \\
\hline & & panoramic & $-58^{\circ}$ & .06 & .00 \\
\hline & panoramic & whole head & $-46^{\circ}$ & .06 & .00 \\
\hline & & lateral ceph & $.58^{\circ}$ & .06 & .00 \\
\hline Skin & whole head & lateral ceph & $1.76^{\circ}$ & .06 & .00 \\
\hline & & panoramic & $1.18^{\circ}$ & .06 & .00 \\
\hline & lateral ceph & whole head & $-1.76^{\circ}$ & .06 & .00 \\
\hline & & panoramic & $.59^{\circ}$ & .06 & .00 \\
\hline & panoramic & whole head & $-1.18^{\circ}$ & .06 & .00 \\
\hline & & lateral ceph & $.59^{\circ}$ & .06 & .00 \\
\hline Bone Surface & whole head & lateral ceph & $.53^{\circ}$ & .06 & .00 \\
\hline & & panoramic & $1.35^{\circ}$ & .06 & .00 \\
\hline & lateral ceph & whole head & $-.53^{\circ}$ & .06 & .00 \\
\hline & & panoramic & $82^{\circ}$ & .06 & .00 \\
\hline & panoramic & whole head & $-1.35^{\circ}$ & .06 & .00 \\
\hline & & lateral ceph & $-82^{\circ}$ & .06 & .00 \\
\hline Mandible & whole head & lateral ceph & $2.01^{\circ}$ & .06 & .00 \\
\hline & & panoramic & $.72^{\circ}$ & .06 & .00 \\
\hline & lateral ceph & whole head & $-2.01^{\circ}$ & .06 & .00 \\
\hline & & panoramic & $-1.29^{\circ}$ & .06 & .00 \\
\hline & panoramic & whole head & $.72^{\circ}$ & .06 & .00 \\
\hline & & lateral ceph & $1.29^{\circ}$ & .06 & .00 \\
\hline Calvarium & whole head & lateral ceph & $.25^{\circ}$ & .07 & .00 \\
\hline & & panoramic & $2.37^{\circ}$ & .07 & .00 \\
\hline & lateral ceph & whole head & $-25^{\circ}$ & .07 & .00 \\
\hline & & panoramic & $2.12^{\circ}$ & .07 & .00 \\
\hline & panoramic & whole head & $-2.37^{\circ}$ & .07 & .00 \\
\hline & & lateral ceph & $-2.12^{\circ}$ & .07 & .00 \\
\hline
\end{tabular}

Goren AD | Volume 2; Issue 2 (2021) | JDHOR-2(2)-026 | Data Article

Citation: Goren AD, et al. Dosimetry Comparison of CBCT versus Digital 2D Orthodontic Imaging in a Pediatric Orthodontic Patient. J Dental Health Oral Res. 2021;2(2):1-28. 


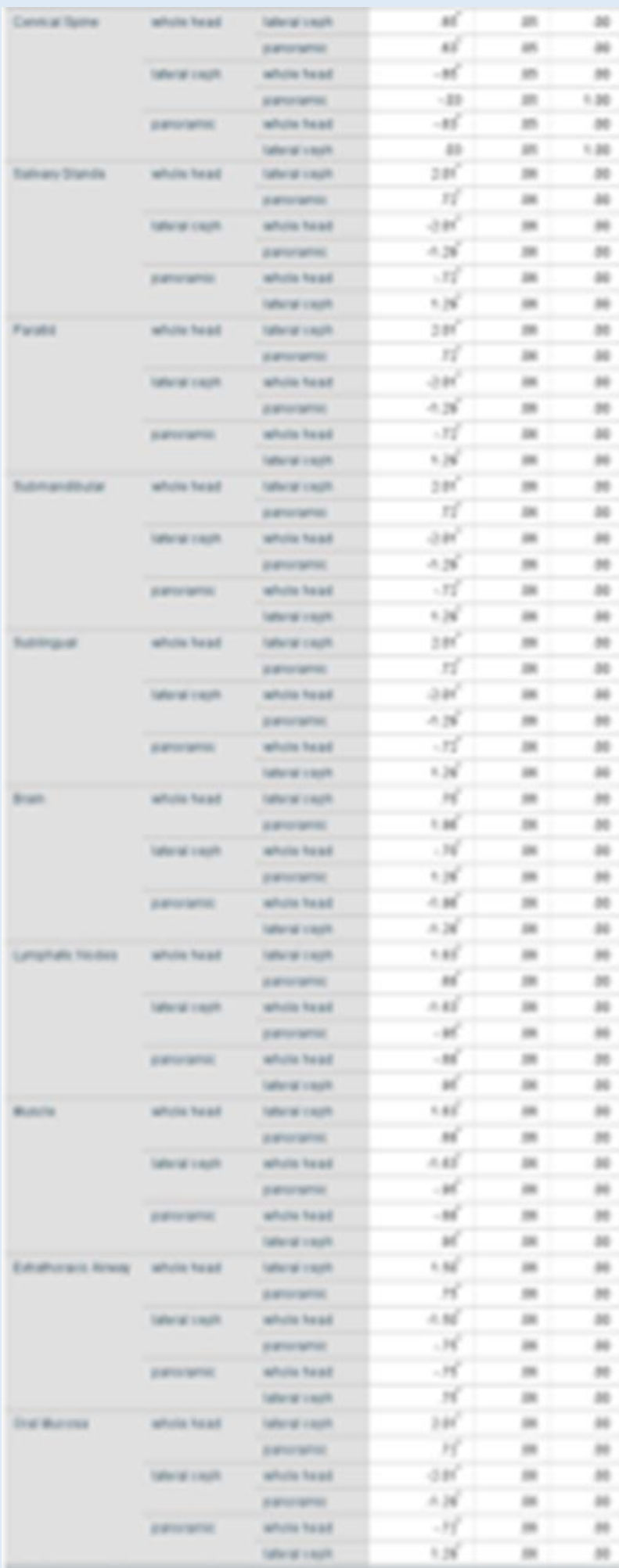

Table 6: Bonferroni multiple comparisons test, absorbed doses. All imaging modalities showed statistically significant differences to one another for all absorbed organ doses except for the cervical spine (highlighted in red). 


\section{Descriptive Statistics}

\begin{tabular}{|c|c|c|c|c|c|c|}
\hline perspective & & $\mathrm{N}$ & Minimum & Maximum & Mean & Std. Deviation \\
\hline \multirow[t]{13}{*}{ whole head } & bone_marrow & 11 & 2.09 & 3.57 & 3.00 & .44 \\
\hline & thyroid & 11 & 3.01 & 4.75 & 3.99 & .55 \\
\hline & esophagus & 11 & .60 & .95 & .80 & .11 \\
\hline & skin & 11 & .15 & .27 & .23 & .04 \\
\hline & Bone_surface & 11 & .73 & 1.24 & 1.05 & .15 \\
\hline & Salivary_Glands & 11 & 8.90 & 19.17 & 16.05 & 2.88 \\
\hline & Brain & 11 & .97 & 1.55 & 1.31 & .18 \\
\hline & Lymphatic_Nodes & 11 & .09 & .18 & .15 & .03 \\
\hline & Muscle & 11 & .09 & .18 & .15 & .03 \\
\hline & Extrathoracid_Airway & 11 & 1.35 & 2.66 & 2.23 & .37 \\
\hline & Oral_Mucosa & 11 & 2.74 & 5.90 & 4.94 & .89 \\
\hline & Lens_of_Eye & 11 & 296.80 & 460.20 & 392.35 & 50.80 \\
\hline & Valid N (listwise) & 11 & & & & \\
\hline \multirow[t]{13}{*}{ lateral } & bone_marrow & 11 & 1.46 & 2.11 & 1.76 & .21 \\
\hline & thyroid & 11 & 1.11 & 1.77 & 1.41 & .21 \\
\hline & esophagus & 11 & .22 & .35 & .28 & .04 \\
\hline & skin & 11 & .03 & .05 & .04 & .01 \\
\hline & Bone_surface & 11 & .51 & .74 & .61 & .07 \\
\hline & Salivary_Glands & 11 & 1.75 & 2.58 & 2.13 & .26 \\
\hline & Brain & 11 & .53 & .79 & .65 & .08 \\
\hline & Lymphatic_Nodes & 11 & .02 & .04 & .03 & .01 \\
\hline & Muscle & 11 & .02 & .04 & .03 & .01 \\
\hline & Extrathoracid_Airway & 11 & .40 & .60 & .49 & .06 \\
\hline & Oral_Mucosa & 11 & .54 & .79 & .65 & .08 \\
\hline & Lens_of_Eye & 11 & 72.00 & 105.00 & 87.00 & 10.44 \\
\hline & Valid N (listwise) & 11 & & & & \\
\hline \multirow[t]{13}{*}{ panoramic } & bone_marrow & 11 & .66 & 1.02 & .77 & .10 \\
\hline & thyroid & 11 & 2.20 & 3.25 & 2.52 & .29 \\
\hline & esophagus & 11 & .44 & .65 & .50 & .06 \\
\hline & skin & 11 & .06 & .09 & .07 & .01 \\
\hline & Bone_surface & 11 & .23 & .36 & .27 & .03 \\
\hline & Salivary_Glands & 11 & 6.88 & 9.66 & 7.72 & .75 \\
\hline & Brain & 11 & .15 & .26 & .18 & .03 \\
\hline & Lymphatic_Nodes & 11 & .07 & .10 & .08 & .01 \\
\hline & Muscle & 11 & .07 & .10 & .08 & .01 \\
\hline & Extrathoracid_Airway & 11 & .92 & 1.32 & 1.04 & .11 \\
\hline & Oral_Mucosa & 11 & 2.12 & 2.97 & 2.38 & .23 \\
\hline & Lens_of_Eye & 11 & 22.00 & 36.00 & 26.30 & 3.75 \\
\hline & Valid N (listwise) & 11 & & & & \\
\hline
\end{tabular}

Table 7: Equivalent doses ( $\mu \mathrm{Sv}$ ) for the pediatric phantom by organ. The highest mean equivalent doses were measured at the salivary gland and lens of eye (highlighted in red). 
ANOVA for log transformed equivalent dose data

\begin{tabular}{|c|c|c|c|c|c|c|}
\hline & & $\begin{array}{l}\text { Sum of } \\
\text { Squares }\end{array}$ & df & Mean Square & $\mathrm{F}$ & Sig. \\
\hline \multirow[t]{3}{*}{ Bone Marrow } & Between Groups & 10.234 & 2 & 5.117 & 295.564 & .000 \\
\hline & Within Groups & .519 & 30 & .017 & & \\
\hline & Total & 10.754 & 32 & & & \\
\hline \multirow[t]{3}{*}{ Thyroid } & Between Groups & 5.998 & 2 & 2.999 & 168.925 & .000 \\
\hline & Within Groups & .533 & 30 & .018 & & \\
\hline & Total & 6.531 & 32 & & & \\
\hline \multirow[t]{3}{*}{ Esophagus } & Between Groups & 5.977 & 2 & 2.988 & 169.868 & .000 \\
\hline & Within Groups & .528 & 30 & .018 & & \\
\hline & Total & 6.505 & 32 & & & \\
\hline \multirow[t]{3}{*}{ Skin } & Between Groups & 17.666 & 2 & 8.833 & 401.271 & .000 \\
\hline & Within Groups & .660 & 30 & .022 & & \\
\hline & Total & 18.326 & 32 & & & \\
\hline \multirow[t]{3}{*}{ Bone Surface } & Between Groups & 10.186 & 2 & 5.093 & 288.435 & .000 \\
\hline & Within Groups & .530 & 30 & .018 & & \\
\hline & Total & 10.716 & 32 & & & \\
\hline \multirow[t]{3}{*}{ Salivary Glands } & Between Groups & 22.835 & 2 & 11.417 & 495.427 & .000 \\
\hline & Within Groups & .691 & 30 & .023 & & \\
\hline & Total & 23.526 & 32 & & & \\
\hline \multirow[t]{3}{*}{ Lymphatic Nodes } & Between Groups & 14.729 & 2 & 7.364 & 223.762 & .000 \\
\hline & Within Groups & .987 & 30 & .033 & & \\
\hline & Total & 15.716 & 32 & & & \\
\hline \multirow[t]{3}{*}{ Muscle } & Between Groups & 14.729 & 2 & 7.364 & 223.762 & .000 \\
\hline & Within Groups & .987 & 30 & .033 & & \\
\hline & Total & 15.716 & 32 & & & \\
\hline \multirow[t]{3}{*}{ Extrathoracic Airway } & Between Groups & 12.412 & 2 & 6.206 & 299.331 & .000 \\
\hline & Within Groups & .622 & 30 & .021 & & \\
\hline & Total & 13.034 & 32 & & & \\
\hline \multirow[t]{3}{*}{ Oral Mucosa } & Between Groups & 22.854 & 2 & 11.427 & 495.411 & .000 \\
\hline & Within Groups & .692 & 30 & .023 & & \\
\hline & Total & 23.546 & 32 & & & \\
\hline
\end{tabular}

Table 8: ANOVA for equivalent doses. ANOVA for equivalent doses. An ANOVA was used to determine whether there were significant differences in the equivalent doses across the three imaging modalities for each organ. Significant differences were found across all organs (highlighted in red).

Goren AD | Volume 2; Issue 2 (2021) | JDHOR-2(2)-026 | Data Article

Citation: Goren AD, et al. Dosimetry Comparison of CBCT versus Digital 2D Orthodontic Imaging in a Pediatric Orthodontic Patient. J Dental Health Oral Res. 2021;2(2):1-28. 


\section{Multiple Comparisons for Log Transformed Equivalent Dose Data}

Bonferroni

\begin{tabular}{|c|c|c|c|c|c|}
\hline Dependent Variable & (l) perspectivee & $(\mathrm{J})$ perspectivee & $\begin{array}{c}\text { Mean } \\
\text { Difference (l- } \\
\mathrm{J}) \\
\end{array}$ & Std. Error & Sig. \\
\hline \multirow[t]{6}{*}{ Bone Marrow } & \multirow[t]{2}{*}{ whole head } & lateral ceph & $.53^{*}$ & .06 & .000 \\
\hline & & panoramic & $1.35^{*}$ & .06 & .000 \\
\hline & \multirow[t]{2}{*}{ lateral ceph } & whole head & $-.53^{*}$ & .06 & .000 \\
\hline & & panoramic & $.82^{*}$ & .06 & .000 \\
\hline & \multirow[t]{2}{*}{ panoramic } & whole head & $-1.35^{*}$ & .06 & .000 \\
\hline & & lateral ceph & $-.82^{*}$ & .06 & .000 \\
\hline \multirow[t]{6}{*}{ Thyroid } & \multirow[t]{2}{*}{ whole head } & lateral ceph & $1.04^{n}$ & .06 & .000 \\
\hline & & panoramic & $.46^{*}$ & .06 & .000 \\
\hline & \multirow[t]{2}{*}{ lateral ceph } & whole head & $-1.04^{n}$ & .06 & .000 \\
\hline & & panoramic & $-.58^{*}$ & .06 & .000 \\
\hline & \multirow[t]{2}{*}{ panoramic } & whole head & $-.46^{n}$ & .06 & .000 \\
\hline & & lateral ceph & $.58^{*}$ & .06 & .000 \\
\hline \multirow[t]{6}{*}{ Esophagus } & \multirow[t]{2}{*}{ whole head } & lateral ceph & $1.04^{\pi}$ & .06 & .000 \\
\hline & & panoramic & $.46^{*}$ & .06 & .000 \\
\hline & \multirow[t]{2}{*}{ lateral ceph } & whole head & $-1.04^{*}$ & .06 & .000 \\
\hline & & panoramic & $-.58^{*}$ & .06 & .000 \\
\hline & \multirow[t]{2}{*}{ panoramic } & whole head & $-.46^{*}$ & .06 & .000 \\
\hline & & lateral ceph & $.58^{*}$ & .06 & .000 \\
\hline \multirow[t]{6}{*}{ Skin } & \multirow[t]{2}{*}{ whole head } & lateral ceph & $1.76^{*}$ & .06 & .000 \\
\hline & & panoramic & $1.19^{*}$ & .06 & .000 \\
\hline & \multirow[t]{2}{*}{ lateral ceph } & whole head & $-1.76^{*}$ & .06 & .000 \\
\hline & & panoramic & $-.57^{*}$ & .06 & .000 \\
\hline & \multirow[t]{2}{*}{ panoramic } & whole head & $-1.19^{*}$ & .06 & .000 \\
\hline & & lateral ceph & $.57^{*}$ & .06 & .000 \\
\hline \multirow[t]{6}{*}{ Bone Surface } & \multirow[t]{2}{*}{ whole head } & lateral ceph & $.53^{*}$ & .06 & .000 \\
\hline & & panoramic & $1.35^{*}$ & .06 & .000 \\
\hline & \multirow[t]{2}{*}{ lateral ceph } & whole head & $-.53^{*}$ & .06 & .000 \\
\hline & & panoramic & $.82^{*}$ & .06 & .000 \\
\hline & \multirow[t]{2}{*}{ panoramic } & whole head & $-1.35^{*}$ & .06 & .000 \\
\hline & & lateral ceph & $-.82^{*}$ & .06 & .000 \\
\hline
\end{tabular}

Goren AD | Volume 2; Issue 2 (2021) | JDHOR-2(2)-026 | Data Article

Citation: Goren AD, et al. Dosimetry Comparison of CBCT versus Digital 2D Orthodontic Imaging in a Pediatric Orthodontic Patient. J Dental Health Oral Res. 2021;2(2):1-28. 


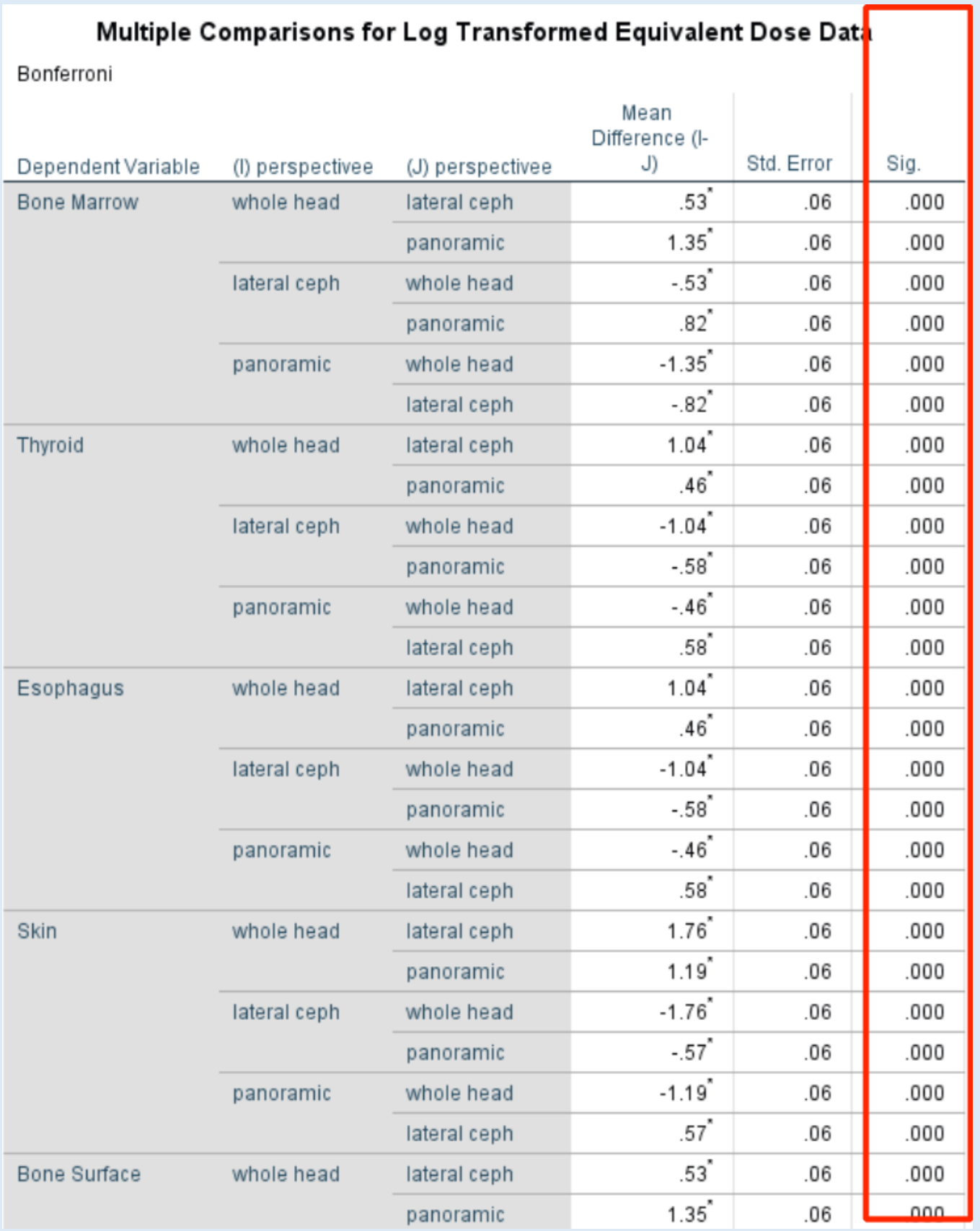

Table 9: Bonferroni Multiple Comparisons Test, Equivalent doses. All imaging modalities showed statistically significant differences to one another for all equivalent organ doses (highlighted in red). 


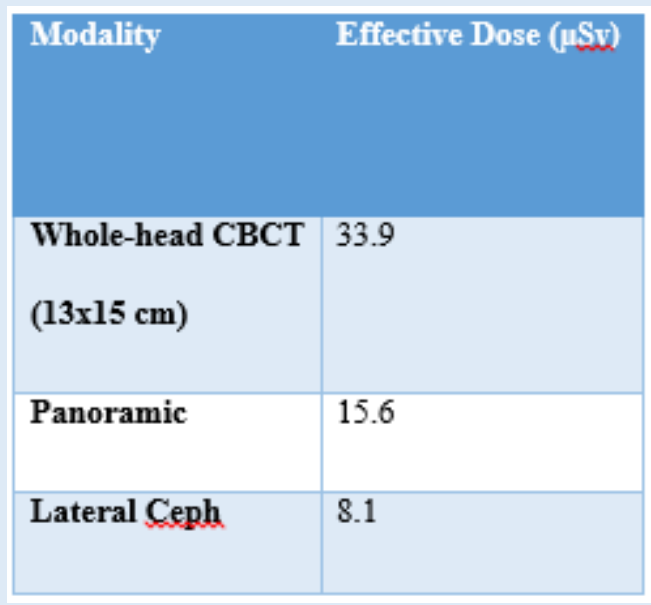

Table 10: Average effective doses across imaging modalities.

\begin{tabular}{|l|l|}
\hline Tissue Irradiated & ICRP-103 Weighting Factor \\
\hline Bone Marrow & 0.12 \\
\hline Thyroid & 0.04 \\
\hline Esophagus & 0.04 \\
\hline Skin & 0.01 \\
\hline Bone Surface & 0.01 \\
\hline Salivary Glands & 0.01 \\
\hline Brain & 0.01 \\
\hline Lymphatic Nodes & 0.00923 \\
\hline Muscle & 0.00923 \\
\hline Extrathoracic Airway & 0.00923 \\
\hline Oral Mucosa & 0.00923 \\
\hline
\end{tabular}

Table 11: Tissue-weighting factors for calculation of equivalent and effective doses based on the ICRP-103 2007 recommendations.

\section{Discussion}

The present study aimed to assess and compare the radiation doses absorbed by various head and neck structures in a typical orthodontic patient during CBCT, digital panoramic, and digital lateral cephalometric imaging using the same machine. The ultimate goal of the study was to help support clinical recommendations for the use of CBCT imaging during orthodontic diagnosis and treatment planning of pediatric patients. Orthodontics has seen a rise in the use of CBCT imaging in diagnosis in treatment planning for the past decade, yet there is still a need for more information regarding the safety of its routine use in the pediatric population. Previous studies that have compared patient absorbed, equivalent, and effective doses of CBCT versus 
2D digital imaging have focused on the adult population, which is not representative of the average orthodontic patient [7,14-17]. In previous studies, various company's machines have been tested. This is the first study that has specifically compared CBCT versus 2D digital imaging dosimetry in the pediatric population using the same machine for all modalities.

Using the same machine is perhaps more representative of a typical office-based clinical scenario where a practitioner may have a single machine for all imaging purposes. Using the same machine for all three modalities may control for fluctuations in X-ray beam intensity between different machines, as well as slight variations in voltages that different machines may have. Unlike previous studies comparing the different modalities, this study used a 10-year-old anthropomorphic phantom that is more representative of the typical orthodontic patient. Even though orthodontic practices are seeing an increase in the number of adult patients, the pediatric population is more vulnerable to the effects of radiation-it is therefore imperative that a comparison in dosimetry reading between $\mathrm{CBCT}$ and traditional modalities is assessed specifically in this population.

The main finding in this study was that there were statistically significant differences in the absorbed and effective doses between whole-head CBCT, digital panoramic, and digital lateral cephalometric imaging across every organ except the cervical spine. The general trend across all absorbed and equivalent doses for each organ was that whole-head CBCT imaging produced the largest doses, followed by panoramic, and then lateral cephalometric imaging in the pediatric patient. The effective doses followed the same trend. The cervical spine in children is more inferior than the other organs assessed, so this may account for nonsignificant differences in the three imaging modalities, as it is further away from the field of view. These nonsignificant findings are also consistent with the fact that the cervical spine received the lowest absorbed dose during whole-head CBCT scans $(4.11 \mu \mathrm{Gy})$, therefore rendering the whole-head CBCT dose reading to be more similar in magnitude than the lateral cephalometric and panoramic readings. Just as in previous studies using adult anthropomorphic phantoms, the salivary glands received the highest absorbed and equivalent dose readings in the pediatric patient [17]. In both adults and in pediatric patients, the salivary glands are in the center of the field of view during all three imaging modalities and is therefore vulnerable to higher exposure. When the effective dose of digital panoramic and lateral cephalometric imaging was summed $(23.7 \mu \mathrm{Sv})$, it was shown to be $43 \%$ less in dose than the single whole-head CBCT scan $(33.9 \mu \mathrm{Sv})$.

Though it is difficult to quantify what the radiation effects may be for a patient over their lifetime, to follow the principles of ALARA, if there is no direct benefit obtained from the use of CBCT imaging in a patient, it should not be used for diagnosis and treatment planning of pediatric orthodontic patients. Examples of cases where a pediatric orthodontic patient may benefit from the use of CBCT imaging in diagnosis may include craniofacial disorders and

Goren AD | Volume 2; Issue 2 (2021) | JDHOR-2(2)-026 | Data Article

Citation: Goren AD, et al. Dosimetry Comparison of CBCT versus Digital 2D Orthodontic Imaging in

a Pediatric Orthodontic Patient. J Dental Health Oral Res. 2021;2(2):1-28.

DOI: http://dx.doi.org/10.46889/JDHOR.2021.2201 
syndromes, cases with known impactions upon clinical examination, and patients with known airway issues. Regardless of which imaging modality is being used, it always holds true that radiographic imaging should be used only after a thorough clinical exam and determination of the benefit that would be received by the imaging.

In future studies, a comparison could be made in measured doses in the 10 -year old phantom across the different modalities and at different exposure settings. The Instrumentarium OP300 has various pediatric settings. It could be assessed whether the lowest exposures setting of the CBCT may produce a dose similar to that of the $2 \mathrm{D}$ digital imaging modalities at the default machine settings. This may reinforce the importance of the clinician to be cautious in the specific exposure settings used for pediatric patients. A future study may also assess whether there is a statistically difference in dosimetry readings in the pediatric population using a lower resolution CBCT scan such as the Quickscan ${ }^{+}$setting on the i-CAT machine versus 2D imaging modalities. The phantom used was representative of a 10-year old male patient, but a future study may also assess sex differences in measured doses for the pediatric population [20-23]. Perhaps the results of this study will lead to more stringent protocols by governing bodies regarding the use of CBCT in the pediatric population. The previous guidelines set forth by the AAOMR were based on studies using adult anthropomorphic phantoms. With the new data obtained from this study, more specific recommendations should be made regarding the use of CBCT imaging in orthodontic diagnosis and treatment planning for children.

\section{Conclusion}

Despite the benefits of CBCT imaging in orthodontic diagnosis and treatment planning, it is clear that it exposes pediatric patients to higher radiation doses than in panoramic and lateral cephalometric imaging combined. Until governing bodies create stricter guidelines for the use of CBCT imaging in this population, it is the responsibility of the orthodontist to only use whole-head CBCT after thoroughly weighing the benefits that it would provide.

\section{References}

1. Hans MG, Valiathan M, Palomo JM. Cone beam computed tomography: A link with the past, a promise for the future. Semin Orthod. 2011;17(1):81-7.

2. Hans MG, Palomo JM, Valiathan M. History of imaging in orthodontics from Broadbent to cone-beam computed tomography. Am J Orthod Dentofacial Orthop. 2015;148:914-21

3. Broadbent BH. A new X-ray technique and its application to orthodontia. Angle Orthod. 1931;1:45-66.

4. Abdelkarim A, L Jerrold. Clinical considerations and potential liability associated with the use of ionizing radiation in orthodontics. Am J Orthod Dentofacial Orthop. 2018;154:14-25. 
5. Centers for Disease Control and Prevention-As Low As Reasonably Achievable (ALARA). 2015. [Last accessed on May 27, 2021] https://www.cdc.gov/nceh/radiation/alara.html

6. Proffit T. Contemporary orthodontics. Elsevier. 2013;177-203.

7. Silva MA, Wolf U, Heinicke F, Bumann A, Visser H, Hirsch E. Cone-beam computed tomography for routine orthodontic treatment planning: a radiation dose evaluation. Am J Orthod Dentofacial Orthop. 2008; 133(5):640-e1.

8. White Stuart C, Michael J Pharoah. Oral radiology: principles and interpretation. Mosby Elsevier. 2009;1542.

9. Whaites E, Drage N. Essentials of dental radiography and radiology. Elsevier Health Sciences. 2013;57-75.

10. Mountford PJ, Temperton DH. Recommendations of the International Commission On Radiological Protection (ICRP). 1990:77-9.

11. Valentin J. Avoidance of radiation injuries from medical interventional procedures, ICRP Publication. Annals of the ICRP. 2000;30(2):7.

12. Evans CA, Scarfe WC, Ahmad M, Cevidanes LH, Ludlow JB, Palomo JM, et al. Clinical recommendations regarding use of cone beam computed tomography in orthodontics. Position statement by the American Academy of Oral and Maxillofacial Radiology. Oral Surg Oral Med Oral Pathol Oral Radiol. 2013;116(2):238-57.

13. Goren AD, Prins RD, Dauer LT, Quinn B, Al-Najjar A, Faber RD, et al. Effect of leaded glasses and thyroid shielding on cone beam CT radiation dose in an adult female phantom. Dentomaxillofac Radiol. 2013;42(6):20120260.

14. Ludlow JB, Davies-Ludlow LE, Brooks SL. Dosimetry of two extraoral direct digital imaging devices: NewTom cone beam CT and Orthophos Plus DS panoramic unit. Dentomaxillofac Radiol. 2003;32(4):22934.

15. Ludlow JB, Davies-Ludlow LE, Brooks SL, Howerton WB. Dosimetry of 3 CBCT devices for oral and maxillofacial radiology: CB Mercuray, NewTom 3G and i-CAT. Dentomaxillofac Radiol. 2006;35(4);21926.

16. Ludlow JB, Walker C. Assessment of phantom dosimetry and image quality of i-CAT FLX cone-beam computed tomography. Am J Orthod Dentofacial Orthop. 2013;144:802-17.

17. Grünheid T, Schieck JR, Pliska BT, Ahmad M, Larson BE. Dosimetry of a cone-beam computed tomography machine compared with a digital X-ray machine in orthodontic imaging. Am J Orthod Dentofacial Orthop. 2012;141:436-43.

18. Silva MA, Wolf U, Heinicke F, Bumann A, Visser H, Hirsch E. Cone-beam computed tomography for routine orthodontic treatment planning: a radiation dose evaluation. Am J Orthod Dentofacial Orthop. 2008;133(5):640-1.

19. Al Najjar A, Colosi D, Dauer LT, Prins R, Patchell G, Branets I, et al. Comparison of adult and child radiation equivalent doses from 2 dental cone-beam computed tomography units. Am J Orthod Dentofacial Orthop. 2013;143(6):784-92.

20. Andreo P. Monte Carlo simulations in radiotherapy dosimetry. Radiation Oncol. 2018;13(1):1-5.

21. Dizikes P. Explained: Monte Carlo simulations. MIT News Office. 2010.

22. American association of orthodontists: clinical practice guidelines for orthodontics and dentofacial orthopedics. 2017. [Last accessed on May 27, 2021] https://www.aaoinfo.org/d/apps/get-file?fid=12939

23. American Dental Association (ADA) and the United States Food and Drug Administration (FDA): Dental radiographic examinations, recommendations for patient selection and limiting radiation exposure. 2012. [Last accessed on May 27, 2021]

https://www.ada.org/ /media/ADA/Publications/ADA\%20News/Files/Dental_Radiographic_Examination s_2012.pdf?la=en 